\title{
Spin-Labeled Psoralen Probes for the Study of DNA Dynamics ${ }^{\dagger}$
}

\author{
H. Peter Spielmann, ${ }^{\ddagger}$ Dae-Yoon Chi, ${ }^{\S}$ Nathan G. Hunt," Melvin P. Klein, and John E. Hearst* \\ Structural Biology Division, Lawrence Berkeley Laboratory, and Department of Chemistry, University of California, \\ Berkeley, California 94720
}

Received January 31, 1995; Revised Manuscript Received July 5, $1995^{\circledR}$

\begin{abstract}
Six nitroxide spin-labeled psoralen derivatives have been synthesized and evaluated as probes for structural and dynamic studies. Sequence specific photoaddition of these derivatives to DNA oligonucleotides resulted in site-specifically cross-linked and spin-labeled oligomers. Comparison of the general line shape features of the observed electron paramagnetic resonance (EPR) spectra of several duplexes ranging in size from 8 to 46 base pairs with simulated EPR spectra indicate that the nitroxide spin-label probe reports the global tumbling motion of the oligomers. While there is no apparent large amplitude motion of the psoralen other than the overall tumbling of the DNA on the time scales investigated, there are indications of bending and other residual motions. The (A)BC excinuclease DNA repair system detects structural or dynamic features of the DNA that distinguish between damaged and undamaged DNA and are independent of the intrinsic structure of the lesion. NMR studies have shown that psoralencross-linked DNA has altered backbone dynamics and conformational populations in the immediate vicinity of the adduct [Emsley et al. (1993) J. Am. Chem. Soc. 115, 7765-7771; Spielmann et al. (1995) Proc. Natl. Acad. Sci. U.S.A. 92, 2345-2349]. We suggested that the signal for recognition of a lesion to be repaired is in the sugar-phosphate backbone and not in the damaged base(s).
\end{abstract}

Psoralen-damaged DNA serves as an excellent substrate for the study of structural and dynamic motifs that DNA repair enzyme systems may recognize. Psoralens are photoreagents which form a well-characterized set of covalent nucleic acid adducts through photochemical addition (Figure 1) (Straub et al., 1981; Kanne et al., 1982a,b). The primary reaction is cyclobutane ring formation between the 5,6 double bond of thymidine in DNA and either the $4^{\prime}, 5^{\prime}$ or 3,4 double bonds of the psoralen. Reaction at the $4^{\prime}, 5^{\prime}$ double bond creates a furanside monoadduct (MAf), ${ }^{1}$ which can react further at a site with opposed and adjacent pyrimidines to create an interstrand cross-link (XL). The XL is a rigid unit formed by the psoralen and the opposite and adjacent pyrimidine bases, linking the two strands together. Reaction at the 3,4 double bond of the psoralen first creates a pyroneside monoadduct (MAp), which cannot form an interstrand cross-link.

Psoralen-DNA monoadducts and cross-links are recognized and removed by the excision repair system in both

† This work was supported in part by the National Institutes of Health Grant GM-41911 (J.E.H. and M.P.K.), by postdoctoral fellowship GM14966 (H.P.S.), and by the Director, Office of Energy Research, Office of Basic Energy Sciences, Materials Sciences Division of the U.S. Department of Energy, under Contract No. DE-AC03-76SF00098 (J.E.H. and M.P.K.).

* Author to whom correspondence should be addressed

† Present address: Department of Biochemistry, University of Kentucky, 800 Rose Street, Lexington, KY 40536-0084.

$\$$ Present address: Division of Nuclear Medicine, Samsung Hospital, 50 Ilwondong Kangnamgu, Seoul, Korea 135-230.

"Present address: Department of Pharmaceutical Chemistry, University of California, San Francisco, CA 94143.

${ }^{\otimes}$ Abstract published in Advance ACS Abstracts, November 1, 1995.

'Abbreviations: EPR, electron paramagnetic resonance; MAf, psoralen-DNA furanside monoadduct; XL, psoralen-DNA interstrand cross-link; MAp, psoralen-DNA pyroneside monoadduct; NMR, nuclear magnetic resonance; 2-D NMR, two-dimensional NMR; AMT, $4^{\prime}$-(aminomethyl)-4,5',8-trimethylpsoralen; HMT, 4' -(hydroxymethyl)4,5',8-trimethylpsoralen; 8-MOP, 8-methoxypsoralen; bp, base pair.
(1)

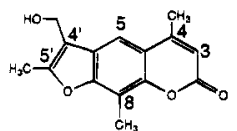

(2)

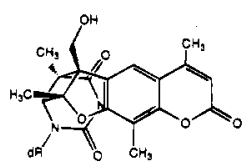

(3)

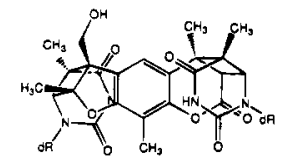

(4)

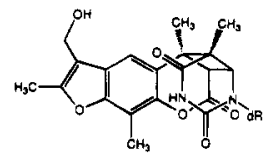

FIGURE 1: Structures and numbering schemes of HMT (1b) and the most common HMT-nucleoside adducts.

bacteria and higher organisms (Sancar \& Sancar, 1988; Reardon et al., 1991). There are a large number of structurally unrelated DNA lesion-forming agents that are efficiently removed by the excision repair system (Sancar \& Sancar, 1988; Smith, 1988; Van Houten et al., 1987, 1988; Sladek et al., 1989; Smith et al., 1989; Cheng et al., 1991; Reardon et al., 1991; Huang et al., 1994). The sequence dependent microstructures in normal DNA are not recognized as damaged by these systems. It has been proposed that the recognition of lesions in DNA takes place by the recognition of either (or both) structural distortions or dynamic changes in the polymer (Sancar \& Sancar, 1988; Lin \& Sancar, 1989; $\mathrm{Pu}$ et al., 1989). It has also been proposed that DNA damage causes local instability in the helix and that the (A)BC excision repair system recognizes an excessive or unusual deformability (Williams \& Gao, 1992). 
The reactivity of some proteins with DNA has been postulated to involve a "molecular matchmaking" event which requires the structural reorganization of the target DNA sequence by an energy-utilizing step through ATP hydrolysis (Sancar \& Hearst, 1993). The matchmaking mechanism uncouples the damage recognition event by UvrA from the subsequent excision steps by $\mathrm{UvrB}$ and $\mathrm{UvrC}$. Repair of DNA damage sites by (A)BC excinuclease may be targeted to an altered and more complex range of conformations available to the damaged DNA with respect to undamaged DNA rather than through recognition of a particular static structural distortion of the helix (Lin \& Sancar, 1989; Pu et al., 1989). Our objective is to understand these altered conformations in damaged DNA as they are revealed by changes in the helix dynamics of damaged DNA in order to establish a relationship between such changes and the repair process.

The structures of the $4^{\prime}$-(hydroxymethyl)-4,5',8-trimethylpsoralen (HMT, 1b) cross-link and furanside monoadduct in the oligonucleotide $\mathrm{d}(\mathrm{GCGTACGC})_{2}$ have been determined by ${ }^{1} \mathrm{H}$ NMR (nuclear magnetic resonance) (Spielmann et al., 1995). These studies suggest that the structural perturbation induced by the adducts is localized to the three base pairs on either side of the damage and that the DNA axis is not bent. These structural perturbations also cause changes in the conformational equilibria of the sugarphosphate backbones near the damage site. NMR analysis of the deoxyribose conformations of the sugars adjacent to and involved in the psoraien adduct suggests that the HMT damage destabilizes the preference for the $\mathrm{C}^{\prime}$ endo sugar conformation, permitting the sugars in proximity to the damage to adopt a larger range of rapidly interconverting conformers with a significantly altered population distribution relative to unmodified DNA (Emsley et al., 1993). These changes in the equilibrium distribution of the deoxyribose conformations observed in the XL may be recognized as the signal that positions the DNA repair system at the location of the DNA damage.

NMR studies of short DNA oligomer dynamics have provided some motivation for an electron paramagnetic resonance spectroscopy (EPR) study in order to establish the time scale over which conformational changes take place. NMR results have been interpreted in terms of motions over a time range of 10 orders of magnitude (Opella et al., 1981; Eimer et al., 1990; Borer et al., 1994; Nuutero et al., 1994). However, no good estimates of the time required for either local or collective angular motions of the bases are available, except that they are rapid relative to the tumbling times. The motions of the bases in the helix have been studied by fluorescence polarization anisotropy [for a review, see Schurr et al. (1992)]. EPR is a technique that has been used to study dynami processes in the milli- to nanosecond time regime. Early EPR studies of nucleic acids involved the use of spin-labeled tRNA to investigate tRNA dynamics [for a review, see Dugas (1977)]. Since then, different methods and techniques have been developed to prepare spin-labeled nucleic acids and to use spin labeling to study the physical and biochemical properties of nucleic acids (Bobst, 1979; Kamzolova \& Postnikova, 1981). A family of nitroxide spinlabeled reagents that bind to nucleic acids by noncovalent intercalation have been developed which have dynamic motions that are independent of the nucleic acid that they are bound to on the nanosecond time scale. EPR has been
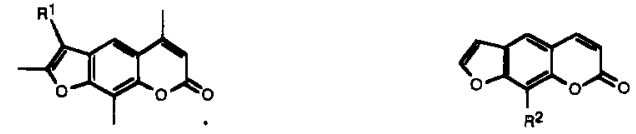

1a $\quad \mathrm{R}^{9}=\mathrm{CH}_{2} \mathrm{NH}_{2}$

16 $\mathrm{R}^{1}=\mathrm{CH}_{2} \mathrm{OH}$

$13 \mathrm{R}^{1}=\mathrm{CH}_{2} \mathrm{Cl}$

$3 \mathrm{~A}^{1}={ }^{-\mathrm{CH}_{2} \mathrm{NHCH}_{2}}$

$\mathrm{R}^{2}=\mathrm{OCH}_{3}$

$15 \mathrm{R}^{2}=\mathrm{OH}$

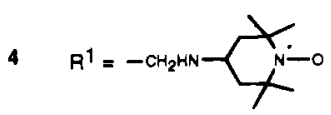

$6 R^{2}=$

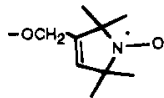

$7 \mathrm{R}^{2}=-\mathrm{OCH}_{2} \mathrm{CNH}-\mathrm{N}_{\mathrm{N}}^{\mathrm{O}} \mathrm{O}$

$5 \quad \mathrm{R}^{1}={ }_{-\mathrm{CH}_{2} \mathrm{NHCH}_{2}}^{\mathrm{HO}} \mathrm{N}^{\mathrm{N}} \mathrm{O}$

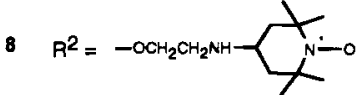

FIGURE 2: Structures of new spin-labeled psoralens.

used to measure motions of spin-labeled intercalators bound to DNA (Robinson et al., 1980). Motions on a 40 ns time scale have been detected by this method and interprted as torsional base motion.

Site-specific covalent spin-labeling methods for nucleic acids have been carried out in some selected tRNAs containing minor bases in positions known from sequencing (Bobst, 1979). Direct attachment of a spin-labeled probe to DNA has been accomplished using both enzymatic and chemical syntheses (Bobst et al., 1984; Kao \& Bobst, 1985; Pauly et al., 1987; Spaltenstein et al., 1989; Kirchner et al., 1990). It is clear from these studies that the length and structure of the tether which connects the nitroxide reporter group to the DNA have a profound influence on the EPR spectra obtained. Long tethers that permitted free rotation of the probe relative to the DNA are unable to give spectra with correlation times greater than a few nanoseconds. A nitroxide spin-label analog of thymidine in which the methyl group is replaced by an acetylene-tethered spin-label sitespecifically incorporated by chemical synthesis into DNA oligomers has given spectra that can be interpreted as arising from isotropic rotational correlation times of up to $100 \mathrm{~ns}$ (Spaltenstein et al., 1989). Steric inhibition of rotation of the nitroxide by the surrounding DNA has been implicated as the factor that allows such long correlation times to be observed (Kirchner et al., 1990). A significant amplitude of bending in addition to the overall anisotropic rigid body motion was found for a $46 \mathrm{bp}$ duplex labeled with this probe (Hustedt et al., 1993, 1995).

We have developed new psoralen nitroxide spin probes (3-8, Figure 2) to investigate potential damage-induced changes in the dynamics of the helix that have (1) essentially the same photoreactivity as the parent psoralen, (2) substantially the same adduct structure as the non-spin-labeled psoralens, and (3) a linker arm to the spin-label probe that minimizes or eliminates motion which is independent of the psoralen and its relationship to the DNA. We wish to determine the connection between the altered and more complex range of conformations in the deoxyribose backbone which have been observed by 2-D NMR in a psoralen-crosslinked oligomer and vibrational dynamics of the adjacent bases and psoralen. The goal of the present work is the synthesis of suitable probes to explore the damage dependent dynamics of nucleic acids by using EPR.

A preliminary account of the photochemical characterization of these molecules was reported in Shi et al. (1990). 
We describe the structural and dynamic properties of the photoalkylated DNA and suggest what the implications that these changes in structure and dynamics may have for cellular DNA repair processes.

\section{MATERIALS AND METHODS}

Pyridine and tetrahydrofuran (THF) were distilled from sodium benzophenone ketyl. $N, N$-Dimethylformamide (DMF) was distilled from phosphorus pentoxide. Column chromatography was done by flash chromatography with 40-63 $\mu \mathrm{m}$ silica gel 60 (EM Reagents). High-performance liquid chromatography (HPLC) was performed using a $10 \mathrm{~mm} \times$ $25 \mathrm{~cm} 5 \mu \mathrm{m}$ Ultrasphere ODS preparative column (Altex). HMT, 4' -(aminomethyl)-4,5',8-trimethylpsoralen (AMT), and $4^{\prime}$-(chloromethyl)-4,5',8-trimethylporalen (CMT) were gifts from HRI Associates Inc. (Concord, CA). Nitroxide spin label starting materials were purchased from Molecular Probes Inc. (Portland, OR). The oligonucleotides were synthesized on an automated DNA synthesizer using the phosphoramadite method. After synthesis, the oligonucleotide was deprotected in concentrated ammonia solution at $55^{\circ} \mathrm{C}$ for $5-16 \mathrm{~h}$ and purified by electrophoresis on a $20 \%$ polyacrylamide $-7 \mathrm{M}$ urea gel, followed by ethanol precipitation. The purification gel $(40 \mathrm{~cm} \times 40 \mathrm{~cm} \times 0.12 \mathrm{~cm})$ had a composition of 19:1 acrylamide/bis(acrylamide) and was run at $45 \mathrm{~W}$ with an aluminum plate clamped on the gel plate. $\left[\gamma_{-}{ }^{32} \mathrm{P}\right] \mathrm{ATP}$ was purchased from Amersham. T4 polynucleotide kinase and T4 ligase were bought from Bethesda Research Laboratories. All other chemicals were purchased from Aldrich Corp. or Sigma Corp.

${ }^{1} \mathrm{H}$ NMR spectra were obtained with the UCB $250 \mathrm{MHz}$ and UCB $200 \mathrm{MHz}$ spectrometers and are reported in part per million downfield from an internal tetramethylsilane reference. ${ }^{1} \mathrm{H}$ NMR spectra of the nitroxides were acquired by reducing them in situ with phenylhydrazine (Lee \& Keana, 1975). Elemental analyses were performed by the Analytical Laboratory, College of Chemistry, University of California, Berkeley, CA. Mass spectrometry was performed by the Mass Spectrometry Facility, College of Chemistry, University of California, Berkeley, CA.

1-Oxy-3-(hydroxymethyl)-2,2,5,5-tetramethyl-3-pyrroline (10). Carboxylic acid $9(921 \mathrm{mg}, 5 \mathrm{mmol})$ was dissolved in $25 \mathrm{~mL}$ of flash-distilled THF. Lithium aluminum hydride ( $230 \mathrm{mg}, 6 \mathrm{mmol}$ ) was added slowly. After the mixture was stirred for $20 \mathrm{~min}$ at room temperature, the reaction was carefully quenched with $10 \%$ aqueous $\mathrm{NH}_{4} \mathrm{Cl}$ solution. Sodium chloride and $\mathrm{CHCl}_{3}(30 \mathrm{~mL})$ were added, and the mixture was filtered. The chloroform solution was dried $\left(\mathrm{Na}_{2} \mathrm{SO}_{4}\right)$ and evaporated to dryness, giving $500 \mathrm{mg}(59 \%)$ of yellow crystalline $\mathbf{1 0}$ (this crude crystal was used for the following mesylation reaction without further purification): ${ }^{1} \mathrm{H}$ NMR of 1-hydroxy-3-(hydroxymethyl)-2,2,5,5-tetramethyl-3-pyrroline (200 $\left.\mathrm{MHz}, \mathrm{CDCl}_{3}\right) \delta 1.36\left(\mathrm{~s}, 6,2 \mathrm{CH}_{3}\right)$, 1.39 (s, 6, 2CH 3 ), 3.4-4.0 (bs, 1, OH), 4.20 (s, 2, $\mathrm{CH}_{2}$ ), $5.62(\mathrm{~s}, 1, \mathrm{CH})$; mass spectrum $(70 \mathrm{eV}) \mathrm{m} / \mathrm{z}$ (relative intensity) $170\left(\mathrm{M}^{+}, 42\right), 155$ (10), 140 (34), 125 (20), 122 (14), 107 (100). Anal. Calcd for $\mathrm{C}_{9} \mathrm{H}_{16} \mathrm{NO}_{2}: \mathrm{C}, 63.50 ; \mathrm{H}$, 9.47; N, 8.23. Found: C, 63.33; H, 9.50; N, 8.07.

1-Oxy-3-[/(methanesulfonyl)oxy]methyl]-2,2,5,5-tetramethyl3-pyrroline (11). The alcohol 10 (494 $\mathrm{mg}, 2.9 \mathrm{mmol})$ was dissolved in dichloromethane $(8.5 \mathrm{~mL})$, and triethylamine (411 mg, $4.1 \mathrm{mmol}$ ) was added. The solution was cooled to $-5{ }^{\circ} \mathrm{C}$. Methanesulfonyl chloride (332 $\mathrm{mg}, 2.9 \mathrm{mmol}$ ) was added dropwise. After the mixture was stirred for 30 $\mathrm{min}$, the reaction was quenched with the aid of more dichloromethane and with ice. The organic layer was washed with cold water and $5 \%$ aqueous sodium bicarbonate and dried $\left(\mathrm{Na}_{2} \mathrm{SO}_{4}\right)$. Removal of solvent in vacuo and flash chromatography gave $567 \mathrm{mg}(79 \%)$ of yellow solid of mesylate 11: ${ }^{1} \mathrm{H}$ NMR of 1-hydroxy-3-[[(methanesulfonyl)oxy]methyl]-2,2,5,5-tetramethylpyrroline $\left(200 \mathrm{MHz}^{\mathrm{CDCl}} \mathrm{CDC}_{3}\right)$ $\delta 1.35\left(\mathrm{~s}, 6,2 \mathrm{CH}_{3}\right), 1.38\left(\mathrm{~s}, 6,2 \mathrm{CH}_{3}\right), 3.05\left(\mathrm{~s}, 3, \mathrm{SCH}_{3}\right)$, 4.73 (s, 1, CH); UV (ethanol) start absorption from $260 \mathrm{~nm}$; mass spectrum $(70 \mathrm{eV}) \mathrm{m} / \mathrm{z}$ (relative intensity) $248\left(\mathrm{M}^{+}, 36\right)$, 233 (12), 218 (3), 153 (5), 138 (9), 122 (18), 107 (100). Anal. Calcd for $\mathrm{C}_{10} \mathrm{H}_{18} \mathrm{NO}_{4} \mathrm{~S}$ : C, 48.37; H, 7.31; N, 5.64; S, 12.91. Found: C, 48.63; H, 7.42; N, 5.65; S, 12.54 .

$4^{\prime}$-[[N-[(1-Oxy-2,2,5,5-tetramethyl-3-pyrrolinyl)methyl]aminolmethyl]-4,5',8-trimethylpsoralen (3). Mesylate 11 (330 $\mathrm{mg}, 6 \mathrm{mmol}$ ) and $4^{\prime}$-(aminomethyl)-4,5',8-trimethylpsoralen (AMT) ( $490 \mathrm{mg}, 1.28 \mathrm{mmol}$ ) were placed in a twonecked flask with a reflux condenser under a nitrogen stream. After addition of DMF ( $3 \mathrm{~mL})$ and triethylamine $(279 \mu \mathrm{L}$, $1.7 \mathrm{mmol}$ ), and solution was kept at $60^{\circ} \mathrm{C}$ for $5 \mathrm{~h}$ with stirring. Then the DMF was evaporated in vacuo, and the residue was partitioned between $5 \%$ aqueous sodium bicarbonate and dichloromethane. The organic layer was dried $\left(\mathrm{Na}_{2} \mathrm{SO}_{4}\right)$ and evaporated in vacuo, giving the crude product. Flash chromatography (silica gel, $4 \%$ ethanol/ $\mathrm{CH}_{2} \mathrm{C}_{12}$ ) and crystallization with ethanol yielded orange crystals of $\mathbf{3}(254$ $\mathrm{mg}, 55 \%):{ }^{1} \mathrm{H}$ NMR of $4^{\prime}$-[[ $N$-[(1-hydroxy-2,2,5,5-tetramethyl-3-pyrrolinyl)methyl]amino]methyl]-4,5',8-trimethylpsoralen $\left(250 \mathrm{MHz}, \mathrm{CDCl}_{3}\right) \delta 1.31\left(\mathrm{~s}, 12,4 \mathrm{CH}_{3}\right), 2.49$ (s, $\left.3, \mathrm{CH}_{3}\right), 2.51\left(\mathrm{~s}, 3, \mathrm{CH}_{3}\right), 2.58\left(\mathrm{~s}, 3, \mathrm{CH}_{3}\right), 3.31$ (s, 2, pyrroline ring- $\left.\mathrm{CH}_{2} \mathrm{~N}\right), 3.94\left(\mathrm{~s}, 2, \mathrm{NCH}_{2}\right.$-psoralen), 5.58 (s, 1, C3-H), 7.73 (s, 1, C5-H); UV (ethanol) $\lambda_{\max } 340,290$, $250 \mathrm{~nm}$; mass spectrum $(70 \mathrm{eV}) \mathrm{m} / \mathrm{z}$ (relative intensity) 409 $\left(\mathrm{M}^{+}\right.$, 33), 395 (5), 379 (11), 256 (6), 240 (100), 212 (10), 138 (10). Anal. Calcd for $\mathrm{C}_{24} \mathrm{H}_{29} \mathrm{~N}_{2} \mathrm{O}_{4}$ : C, 70.39; $\mathrm{H}, 7.14$; N, 6.84. Found: C, 70.18; H, 7.13; N, 6.73.

$4^{\prime}$-[ [N-(1-Oxy-2,2,6,6-tetramethyl-4-piperidinyl)amino]methyl]-4,5',8-trimethylpsoralen (4). To anhydrous $N, N$ dimethylformamide (DMF, $3 \mathrm{~mL}$ ) were added 4 '-(chloromethyl)-4,5',8-trimethylpsoralen (CMT) (55.3 mg, $0.2 \mathrm{mmol}$ ), TEMPAMINE (34 $\mathrm{mg}, 0.2 \mathrm{mmol}$ ), and triethylamine $(20.2$ $\mathrm{mg}, 0.4 \mathrm{mmol}$ ) with stirring. The solution was heated at 70 ${ }^{\circ} \mathrm{C}$ for $16 \mathrm{~h}$ and turned dark brown. The solvent was evaporated. The residue was dissolved in $15 \mathrm{~mL}$ of $\mathrm{CHCl}_{3}$ and extracted once against $10 \mathrm{~mL}$ of $5 \% \mathrm{HCl}$. The organic layer was discarded. $\mathrm{NaOH}(8 \mathrm{M})$ was added to the aqueous layer to $\mathrm{pH} 14$ and extracted three times with $10 \mathrm{~mL}$ of $\mathrm{CHCl}_{3}$. The combined organic extracts were dried over $\mathrm{Na}_{2}-$ $\mathrm{SO}_{4}$ and evaporated. The residue was applied to a $20 \mathrm{~cm} \times$ $20 \mathrm{~cm} \times 2 \mathrm{~mm}$ silica gel TLC plate and developed with $5 \%$ $\mathrm{MeOH} / \mathrm{CHCl}_{3}$. The major UV-absorbing band was scraped off and eluted three times with $20 \mathrm{~mL}$ of $10 \%$ ethanol/ $\mathrm{CHCl}_{3}$. The organics were evaporated to give $70 \mathrm{mg}$ of orange solid (85\% yield): ' $\mathrm{H}$ NMR of 4 '-[[N-(1-hydroxy-2,2,6,6,-tetramethyl-4-piperidinyl)amino]methyl]-4,5',8-trimethylpsoralen $\left(250 \mathrm{MHz}, \mathrm{CDCl}_{3}\right) \delta 6\left(\mathrm{~s}, 8,2 \mathrm{CH}_{3}\right), 1.23\left(\mathrm{~s}, 8,2 \mathrm{CH}_{3}\right)$, $2.49\left(\mathrm{~s}, 3, \mathrm{CH}_{3}\right), 2.51\left(\mathrm{~s}, 3, \mathrm{CH}_{3}\right), 2.53\left(\mathrm{~s}, 3, \mathrm{CH}_{3}\right), 1.91(\mathrm{~m}$, 4, piperidine- $\mathrm{CH}_{2}$ ), 3.87 (s, 2, $\mathrm{NCH}_{2}$-psoralen), 6.26 (s, 1, C3-H), 7.69 (s, 1, C5-H); UV (ethanol) $\lambda_{\max } 340,296,250$ $\mathrm{nm}$; mass spectrum $(70 \mathrm{eV}) \mathrm{m} / \mathrm{z}$ (relative intensity) $412\left(\mathrm{M}^{+}\right.$, 6), $411(8), 379$ (9), 338 (10), 282 (12), 256 (12), 241 (100), 
212 (21), 155 (38), 141 (28), 124 (41), 98 (93), 58 (84). Anal. Calcd for $\mathrm{C}_{24} \mathrm{H}_{31} \mathrm{~N}_{2} \mathrm{O}_{4}:$ C, $70.05 ; \mathrm{H}, 7.59 ; \mathrm{N}, 6.80$. Found: C, 70.04; H, 7.58; N, 6.62.

4'-[[N-[(1-Oxy-4-hydroxy-2,2,6,6-tetramethyl-4-piperidinyl)methyllamino]methyl $7-4,5^{\prime}, 8$-trimethylpsoralen (5). 5,5,7,7Tetramethyl-6-oxy-1-oxa-6-azaspiro[2.5]octane (14) was prepared from TEMPONE and trimethylsulfonium iodide with sodium hydride (Rauckman et al., 1976b). AMT (1, 613 $\mathrm{mg}, 2.38 \mathrm{mmol}$ ) and epoxide $(\mathbf{1 4}, 354 \mathrm{mg}, 1.92 \mathrm{mmol})$ were dissolved in ethanol $(25 \mathrm{~mL})$, and $10 \mathrm{mg}$ of phenol was added as catalyst. The solution was heated at $70^{\circ} \mathrm{C}$ for 4 days. After removal of ethanol, the residue was partitioned between dichloromethane and water. The organic layer was washed with a 5\% aqueous solution of sodium bicarbonate, dried $\left(\mathrm{Na}_{2} \mathrm{SO}_{4}\right)$, and evaporated to give an orange red solid $(837$ $\mathrm{mg})$. Flash chromatography on silica gel $\left(5 \%\right.$ ethanol/ $/ \mathrm{CH}_{2}-$ $\mathrm{Cl}_{2}$ ) followed by recrystallization from ethanol/hexane provided $5(420 \mathrm{mg}, 50 \%):{ }^{1} \mathrm{H}$ NMR of $4^{\prime}-[[\mathrm{N}-[(1,4-$ dihydroxy-2,2,6,6-tetramethyl-4-piperidinyl)methyl]amino]methyl]-4,5',8-trimethylpsoralen $\left(250 \mathrm{MHz}, \mathrm{CDCl}_{3}\right) \delta 1.38$ $\left(\mathrm{s}, 6,2 \mathrm{CH}_{3}\right), 1.50\left(\mathrm{~s}, 6,2 \mathrm{CH}_{3}\right), 2.49\left(\mathrm{~s}, 3,2 \mathrm{CH}_{3}\right), 2.51(\mathrm{~s}, 3$, $\left.2 \mathrm{CH}_{3}\right), 2.56\left(\mathrm{~s}, 3,2 \mathrm{CH}_{3}\right), 2.60\left(\mathrm{~s}, 2\right.$, piperidine ring $\left.-\mathrm{CH}_{2} \mathrm{~N}\right)$, 3.97 (s, 2, $\mathrm{NCH}_{2}$-psoralen), 6.24 (s, 1, C3-H), 7.67 (s, 1, C5-H); UV (ethanol) $\lambda_{\max } 340,297,250 \mathrm{~nm}$; mass spectrum (70 eV) $\mathrm{m} / \mathrm{z}$ (relative intensity) $441\left(\mathrm{M}^{+}, 3\right), 423(2), 408$ (6), 393 (23), 391 (23), 269 (17), 256 (19), 241 (60), 212 (42), 168 (37), 156 (32), 151 (29), 128 (61), 98 (65), 83 (68). Anal. Calcd for $\mathrm{C}_{25} \mathrm{H}_{33} \mathrm{~N}_{2} \mathrm{O}_{5}: \mathrm{C}, 68.01 ; \mathrm{H}, 7.53 ; \mathrm{N}$, 6.34. Found: $\mathrm{C}, 67.97 ; \mathrm{H}, 7.64 ; \mathrm{N}, 6.32$.

8-[(1-Oxy-2,2,5,5-tetramethyl-3-pyrrolinyl)methoxy]psoralen (6). To anhydrous $N, N$-dimethylformamide (DMF, 3 $\mathrm{mL}$ ) were added 8-hydroxypsoralen (15), $(55 \mathrm{mg}, 0.27$ $\mathrm{mmol})$, mesylate $11(79 \mathrm{mg}, 0.27 \mathrm{mmol})$, and potassium carbonate $(68 \mathrm{mg}, 0.49 \mathrm{mmol})$ with stirring. The solution was heated at $70^{\circ} \mathrm{C}$ for $3 \mathrm{~h}$. The solvent was evaporated. The residue was dissolved in dichloromethane and passed through a short silica/ $\mathrm{Na}_{2} \mathrm{SO}_{4}$ column. The solvent was evaporated, providing a yellow solid $6(46 \mathrm{mg}, 48 \%)$ (recrystallized from ethanol): 'H NMR of 8-[(1-hydroxy2,2,5,5-tetramethyl-3-pyrrolinyl)methoxy]psoralen $(250 \mathrm{MHz}$, $\left.\mathrm{CDCl}_{3}\right) \delta 1.23\left(\mathrm{~s}, 6,2 \mathrm{CH}_{3}\right), 1.44\left(\mathrm{~s}, 6,2 \mathrm{CH}_{3}\right), 5.02(\mathrm{~s}, 2$, $\mathrm{OCH}_{2}$-psoralen), 5.83 (s, 1, pyrroline-H), $6.40(\mathrm{~d}, 1, J=$ $9.6 \mathrm{~Hz}, \mathrm{C} 3-\mathrm{H}$ ), 6.83 (peaks of $\mathrm{C} 4{ }^{\prime}-\mathrm{H}$ were overlapped with the peaks of phenylhydrazine), $7.47(\mathrm{~s}, 1, \mathrm{C} 5-\mathrm{H}), 7.75(\mathrm{~d}, 1$, $J=9.7 \mathrm{~Hz}, \mathrm{C} 4-\mathrm{H}), 7.80\left(\mathrm{~s}, 1, \mathrm{C}^{\prime}-\mathrm{H}\right)$; UV (ethanol) $\lambda_{\max }$ 297, 262 (sh), $248 \mathrm{~nm}$. Anal. Calcd for $\mathrm{C}_{20} \mathrm{H}_{20} \mathrm{NO}_{5}$ : C, $67.80 ; \mathrm{H}, 5.65 ; \mathrm{N}, 3.95$. Found: C, 67.88; H, 5.54; N, 6.82.

8-[2-[(1-Oxy-2,2,6,6-tetramethyl-4-piperidinyl)amino]-2oxoethoxy]psoralen (7). To anhydrous $N, N$-dimethylformamide (DMF, $1 \mathrm{~mL}$ ) and benzene $(1 \mathrm{~mL})$ were added 8 -hydroxypsoralen ( $15,55 \mathrm{mg}, 0.27 \mathrm{mmol})$, TEMPO chloracetamide $(\mathbf{1 6}, 0.295 \mathrm{mmol})$, and potassium carbonate $(68$ $\mathrm{mg}, 0.49 \mathrm{mmol}$ ) with stirring. The solution was heated at $70{ }^{\circ} \mathrm{C}$ for $1 \mathrm{~h}$ and turned dark brown. The solvent was evaporated. The residue was dissolved in dichloromethane and passed through a short silica/ $\mathrm{Na}_{2} \mathrm{SO}_{4}$ column, providing a yellow orange solid 7 (110 $\mathrm{mg}, 98 \%)$ (recrystallized from ethanol): 'H NMR of 8-[2-[(1-hydroxy-2,2,6,6-tetramethyl4-piperidinyl)aminol-2-oxoethoxy]psoralen $\left(250 \mathrm{MHz}, \mathrm{CDCl}_{3}\right)$ $\delta 1.47\left(\mathrm{~s}, 6,2 \mathrm{CH}_{3}\right), 1.62\left(\mathrm{~s}, 2 \mathrm{CH}_{3}\right), 2.04-2.32\left(\mathrm{~m}, 4,2 \mathrm{CH}_{2}\right)$, $4.41-4.49$ (m, 1, CH), 4.87 (s, 2, $\left.\mathrm{CH}_{2}\right), 6.40$ (d, $1, J=9.6$ $\mathrm{Hz}, \mathrm{C} 3-\mathrm{H}$ ), 6.85 (peaks of $\mathrm{C}^{\prime}-\mathrm{H}$ were overlapped with the peaks of phenylhydrazine), $7.46(\mathrm{~s}, 1, \mathrm{C} 5-\mathrm{H}), 7.80(\mathrm{~d}, 1, J$ $=9.7 \mathrm{~Hz}, \mathrm{C} 4-\mathrm{H}), 7.88\left(\mathrm{~s}, 1, \mathrm{C} 5^{\prime}-\mathrm{H}\right)$; UV (ethanol) $\lambda_{\max } 297$, $262(\mathrm{sh}), 248 \mathrm{~nm}$; mass spectrum $(70 \mathrm{eV}) \mathrm{m} / \mathrm{z}$ (relative intensity) $413\left(\mathrm{M}^{+}, 20\right), 399$ (26), 384 (20), 327 (31), 260 (70), 215 (62), 202 (59), 154 (72), 140 (70), $126(100), 109$ (78), 84 (95). Anal. Calcd for $\mathrm{C}_{22} \mathrm{H}_{25} \mathrm{~N}_{2} \mathrm{O}_{6}: \mathrm{C}, 63.91 ; \mathrm{H}$, $6.09 ; \mathrm{N}, 6.78$. Found: $\mathrm{C}, 63.77 ; \mathrm{H}, 6.11 ; \mathrm{N}, 6.67$.

8-(2-Hydroxyethoxy)psoralen (17). A mixture of hydroxypsoralen 15 (600 mg, $2.97 \mathrm{mmol}$ ), ethylene carbonate (436 $\mathrm{mg}, 4.95 \mathrm{mmol}$ ), and $\mathrm{K}_{2} \mathrm{CO}_{3}(820 \mathrm{mg}, 5.93 \mathrm{mmol})$ in DMF $(40 \mathrm{~mL})$ was heated at $130{ }^{\circ} \mathrm{C}$ under $\mathrm{N}_{2}$. After $6 \mathrm{~h}$, DMF was evaporated in vacuo, and the residue was partitioned between $30 \mathrm{~mL}$ of water and dichloromethane $(3 \times 30 \mathrm{~mL})$. The combined organic layer was washed with $1 \mathrm{~N}$ sodium hydroxide solution, dried $\left(\mathrm{Na}_{2} \mathrm{SO}_{4}\right)$, and evaporated in vacuo. Flash chromatography (silica gel, $5 \%$ ethanol/ $\mathrm{CH}_{2} \mathrm{Cl}_{2}$ ) gave $485 \mathrm{mg}(66.4 \%)$ of colorless crystalline 17: ${ }^{1} \mathrm{H}$ NMR (200 $\left.\mathrm{MHz}, \mathrm{CDCl}_{3}\right) \delta 2.04$ (bs, 1, OH), $3.97(\mathrm{t}, 2, J=4.5 \mathrm{~Hz}$, $\left.\mathrm{CH}_{2} \mathrm{OH}\right), 4.59\left(\mathrm{t}, 2, J=4.5 \mathrm{~Hz}, \mathrm{OCH}_{2} \mathrm{CH}_{2} \mathrm{OH}\right), 6.39$ (d, 1 , $J=9.6 \mathrm{~Hz}, \mathrm{C} 3-\mathrm{H}), 6.84\left(\mathrm{~d}, 1, J=2.2 \mathrm{~Hz}, \mathrm{C}^{\prime}-\mathrm{H}\right), 7.41(\mathrm{~s}$, $1, \mathrm{C} 5-\mathrm{H}), 7.70\left(\mathrm{~d}, 1, J=2.2 \mathrm{~Hz}, \mathrm{C}^{\prime}-\mathrm{H}\right), 7.78(\mathrm{~d}, 1, J=9.6$ $\mathrm{Hz}, \mathrm{C} 4-\mathrm{H})$; mass spectrum $(70 \mathrm{eV}) \mathrm{m} / \mathrm{z}$ (relative intensity) $246\left(\mathrm{M}^{+}, 36\right), 202(100), 174(55), 89(27)$; exact mass (HREIMS) calcd for $\mathrm{C}_{14} \mathrm{H}_{10} \mathrm{O}_{5} 246.0528$, found 246.0521 .

8-[l(2-Methanesulfonyl)oxy]ethoxy]psoralen (18). The mesylation was performed in a manner similar to the method of compound 11. The alcohol $17(27 \mathrm{mg}, 0.11 \mathrm{mmol})$, triethylamine ( $24.3 \mathrm{mg}, 0.24 \mathrm{mmol}$ ), methanesulfonyl chloride $(18.3 \mathrm{mg}, 0.16 \mathrm{mmol})$, and dichloromethane $(2 \mathrm{~mL})$ were used. The organic layer was passed through neutral alumina $(1 / 2 \mathrm{in}$.) and sodium sulfate $(1 / 2 \mathrm{in}$.), and removal of solvent gave $35 \mathrm{mg}$ (98\%) of colorless crystals of mesylate $\mathbf{1 8}$ (recrystallized from $\left.\mathrm{CH}_{3} \mathrm{CN}\right):{ }^{1} \mathrm{H} \mathrm{NMR}\left(200 \mathrm{MHz}, \mathrm{CDCl}_{3}\right.$ ) $\sigma 3.25\left(\mathrm{~s}, 3, \mathrm{CH}_{3}\right), 4.66\left(\mathrm{t}, 2, J=2.6 \mathrm{~Hz}, \mathrm{CH}_{2}\right), 4.75(\mathrm{t}, 2$, $\left.J=2.6 \mathrm{~Hz}, \mathrm{CH}_{2}\right), 6.39(\mathrm{~d}, 1, J=9.7 \mathrm{~Hz}, \mathrm{C} 3-\mathrm{H}), 6.85(\mathrm{~d}, 1$, $\left.J=2.2 \mathrm{~Hz}, \mathrm{C}^{\prime}-\mathrm{H}\right), 7.42(\mathrm{~s}, 1, \mathrm{C} 5-\mathrm{H}), 7.70(\mathrm{~d}, 1, J=2.2$ $\left.\mathrm{Hz}, \mathrm{C5}^{\prime}-\mathrm{H}\right), 7.78$ (d, $\left.1, J=9.6 \mathrm{~Hz}, \mathrm{C} 4-\mathrm{H}\right)$; mass spectrum $(70 \mathrm{eV}) \mathrm{m} / \mathrm{z}$ (relative intensity) $324\left(\mathrm{M}^{+}, 14\right), 202(13), 201$ (14), 173 (15), 123 (100), 107 (15), 89 (19), 79 (35), 73 (31). Anal. Calcd for $\mathrm{C}_{14} \mathrm{H}_{12} \mathrm{O}_{7} \mathrm{~S}$ : C, $51.84 ; \mathrm{H}, 3.73 ; \mathrm{S}$, 9.89. Found: C, $51.88 ; \mathrm{H}, 3.66 ; \mathrm{S}, 9.76$.

8-[2-[(1-Oxy-2,2,6,6-tetramethyl-4-piperidinyl)amino]ethoxylpsoralen (8). A solution of mesylate $18(160 \mathrm{mg}, 0.49$ mmol), TEMPAMINE (101 $\mathrm{mg}, 0.52 \mathrm{mmol}$ ), and triethylamine $(75 \mathrm{mg}, 0.74 \mathrm{mmol})$ in DMF $(5 \mathrm{~mL})$ was stirred at $90{ }^{\circ} \mathrm{C}$ for $40 \mathrm{~h}$. The solvent was evaporated in vacuo, and the residue was extracted with dichloromethane and water. The organic layer was washed with $5 \%$ aqueous sodium bicarbonate, dried $\left(\mathrm{Na}_{2} \mathrm{SO}_{4}\right)$, and evaporated to provide a crude mixture of 8 . Preparative TLC $(20 \times 20 \mathrm{~cm}, 2 \mathrm{~mm}$, $5 \%$ ethanol/ $\mathrm{CH}_{2} \mathrm{Cl}_{2}$, developed twice) gave $8(118 \mathrm{mg}, 60 \%)$ as a reddish crystal (recrystallized in $\mathrm{CH}_{3} \mathrm{CN}$ ): ${ }^{1} \mathrm{H}$ NMR of 8-[2-[(1-hydroxy-2,2,6,6-tetramethyl-4-piperidinyl)amino]ethoxy]psoralen $\left(250 \mathrm{MHz}, \mathrm{CDCl}_{3}\right) \delta 1.23\left(\mathrm{~s}, 2 \mathrm{CH}_{3}\right), 1.32$ (s, $\left.2 \mathrm{CH}_{3}\right), 1.80$ (m, 4, piperidine ring $-\mathrm{CH}_{2}$ ), 3.34-3.37 (bs, 2, $\left.\mathrm{CH}_{2} \mathrm{~N}\right), 4.78-4.85$ (bs, $\left.4, \mathrm{OCH}_{2}\right), 6.38(\mathrm{~d}, 1, J=9.7 \mathrm{~Hz}$, $\mathrm{C} 3-\mathrm{H}$ ), 6.85 (peaks of $\mathrm{C}^{\prime}-\mathrm{H}$ were overlapped with the peaks of phenylhydrazine), $7.43(\mathrm{~s}, 1, \mathrm{C} 5-\mathrm{H}), 7.71(\mathrm{~m}, 1, J=2.3$ $\left.\mathrm{Hz}, \mathrm{C5}^{\prime}-\mathrm{H}\right), 7.79$ (d, $\left.1, J=9.7 \mathrm{~Hz}, \mathrm{C} 4-\mathrm{H}\right)$; UV (ethanol) $\lambda_{\max } 298,262(\mathrm{sh}), 248 \mathrm{~nm}$; mass spectrum $(70 \mathrm{eV}) \mathrm{m} / \mathrm{z}$ (relative intensity) $400\left(\mathrm{M}^{+}+1,12\right), 399\left(\mathrm{M}^{+}, 4\right), 385(5)$, 384 (2), 396 (6), 326 (66), 312 (53), 298 (75), 202 (48), 183 (33), 169 (73), 112 (59), 98 (90), 96 (82), 84 (100). Anal. 
Calcd for $\mathrm{C}_{22} \mathrm{H}_{27} \mathrm{~N}_{2} \mathrm{O}_{5}$ : C, 66.15; H, 6.81; N, 7.01. Found: C, 66.23; H, 6.79; N, 7.02.

$5^{\prime} \cdot{ }^{32} \mathrm{P}$ End Labeling of DNA Oligonucleotides. The oligonucleotides were $5^{\prime}$-end-labeled with $\left[\gamma-{ }^{32} \mathrm{P}\right] \mathrm{ATP}$ and T4 polynucleotide kinase according to standard procedures (Maniatis et al., 1982). A 1X linker kinase buffer (70 mM Tris- $\mathrm{HCl}, 10 \mathrm{mM} \mathrm{MgCl}_{2}, 5 \mathrm{mM}$ dithiothreitol, $\mathrm{pH}$ 7.6) containing the oligonucleotide to be labeled, $[\gamma-32 \mathrm{P}] \mathrm{ATP}$, and 10 units of kinase were incubated at $37^{\circ} \mathrm{C}$ for $2 \mathrm{~h}$. ATP was added to a final concentration of $1 \mathrm{mM}$. Another 10 units of kinase and $10 \mathrm{X}$ linker kinase buffer were added to maintain a $1 \mathrm{X}$ buffer concentration, and the mixture was incubated at $37^{\circ} \mathrm{C}$ for $2 \mathrm{~h}$. A third aliquot of kinase was added, and the solution was incubated again at $37^{\circ} \mathrm{C}$ for 2 h. The mixture either was used directly or was ethanolprecipitated ( $10 \mathrm{mM} \mathrm{MgCl}, 0.2 \mathrm{~N} \mathrm{NaCl}, 2.5 \mathrm{v} / \mathrm{v}$ ethanol). After ethanol precipitation, the DNA was then dissolved in water or the appropriate buffer and stored at $-20{ }^{\circ} \mathrm{C}$.

Photoreactions of Spin-Labeled Psoralens. Each reaction was performed by irradiating a $50 \mu \mathrm{L}$ volume containing 10 $\mu \mathrm{g} / \mathrm{mL}$ of the appropriate psoralen, $10 \mathrm{ng}$ of $5^{\prime}-{ }^{32} \mathrm{P}$-labeled 5'-GGGTACCC-3', $150 \mathrm{mM} \mathrm{NaCl}, 10 \mathrm{mM} \mathrm{MgCl}$, and 10 $\mathrm{mM}$ Tris- $\mathrm{HCl}$ ( $\mathrm{pH} 7.5$ ) for $10 \mathrm{~min}$ with $300 \mathrm{~mW} / \mathrm{cm}^{2} 320-$ $380 \mathrm{~nm}$ light (Cimino et al., 1986). The irradiated DNA was ethanol-precipitated and electrophoresed on a $20 \%$ polyacrylamide $-7 \mathrm{M}$ urea gel $(40 \mathrm{~cm} \times 40 \mathrm{~cm} \times 0.05 \mathrm{~cm}$, $35 \mathrm{~W}$ for $3-4 \mathrm{~h}$ ). The cross-link and the unmodified DNA bands were located by autoradiography, excised, and eluted from the gel with a solution of $50 \mathrm{mM} \mathrm{NaCl}-1 \mathrm{mM}$ EDTA. The unmodified DNA and cross-link were finally ethanolprecipitated, washed, and dissolved each in $200 \mu \mathrm{L}$ of $\mathrm{H}_{2} \mathrm{O}$. Quantitative measurement of the extent of reaction was obtained by measuring the ${ }^{32} \mathrm{P}$ in each by scintillation counting.

Photoreversal of Psoralen Cross-Links. The gel-purified cross-linked DNAs were dissolved in $100 \mu \mathrm{L}$ of TE and irradiated under a germicidal lamp (Sylvania model G30T8) with its maximum emission at $254 \mathrm{~nm}$ for $2.5 \mathrm{~min}$ at a distance of $10 \mathrm{~cm}$ from the lamp to the surface of the solution (Gamper et al., 1984). The reaction mixture was lyophilized, resuspended in $10 \mathrm{M}$ urea, and electrophoresed on a $7 \mathrm{M}$ urea-20\% polyacrylamide gel.

Preparation of Psoralen 3 Cross-Linked Double-Stranded $5^{\prime}-G G G T A C C C-3^{\prime}$. The cross-link was prepared following the procedures of Cimino et al. (1986). A total of $400 \mu \mathrm{g}$ of $5^{\prime}$-GGGTACCC-3' was dissolved in $700 \mu \mathrm{L}$ of irradiation buffer (50 mM Tris- $\mathrm{HCl}, 0.1 \mathrm{mM}$ EDTA, $150 \mathrm{mM} \mathrm{NaCl}$, $10 \mathrm{mM} \mathrm{MgCl}_{2}, \mathrm{pH}$ 7.6) after kinasing and ethanol precipitation. Concentrated psoralen $3-\mathrm{DMSO}$ solution $(15 \mu \mathrm{L})$ was added to the reaction mixture (final psoralen 3 concentration was $1.5 \times 10^{-4} \mathrm{M}$ ). The mixture was irradiated in a $4 \mathrm{~mL}$ $1 \mathrm{~cm}$ path length quartz cuvette for $10 \mathrm{~min}$ at $4{ }^{\circ} \mathrm{C}$ with broad band light from a $2.5 \mathrm{~kW} \mathrm{Hg} / \mathrm{Xe} \mathrm{lamp,} \mathrm{which} \mathrm{was}$ filtered through Pyrex glass and an aqueous cobaltous nitrate solution [1.7\% $\mathrm{Co}\left(\mathrm{NO}_{3}\right)_{2}, 2 \% \mathrm{NaCl}, 9 \mathrm{~cm}$ path length] (320$380 \mathrm{~nm}, 300 \mathrm{~mW} / \mathrm{cm}^{2}$; Cimino et al., 1986). The irradiated DNA was ethanol-precipitated and electrophoresed on a $20 \%$ polyacrylamide $-7 \mathrm{M}$ urea gel $(40 \mathrm{~cm} \times 40 \mathrm{~cm} \times 0.05 \mathrm{~cm}$, $35 \mathrm{~W}$ for $3-4 \mathrm{~h}$ ). The cross-link and the unmodified DNA bands were located by autoradiography, excised, and eluted from the gel with a solution of $50 \mathrm{mM} \mathrm{NaCl}-1 \mathrm{mM}$ EDTA. The unmodified DNA and cross-link were finally ethanolprecipitated, washed, and dissolved each in $200 \mu \mathrm{L}$ of $\mathrm{H}_{2} \mathrm{O}$.
The unmodified DNA was stored at $-20{ }^{\circ} \mathrm{C}$ and the crosslink at $4{ }^{\circ} \mathrm{C}$.

Synthesis of Modified Oligonucleotides Using the Argon Lasers. Irradiations were carried out with a SpectraPhysics 2045 argon laser operating in broad band mode centered at $366 \mathrm{~nm}$ at a power of $5.0 \mathrm{~W}$. The $5^{\prime}-\mathrm{OH}$ oligonucleotides were dissolved in $35 \mathrm{~mL}$ of $150 \mathrm{mM} \mathrm{NaCl}, 10 \mathrm{mM} \mathrm{MgCl}_{2}$, $1 \mathrm{mM}$ EDTA, $15 \mathrm{mM}$ azide, and $3.5 \times 10^{-5} \mathrm{M}$ of the desired spin-labeled psoralen. This solution was passed through a $1 \mathrm{~cm}$ path length quartz flow cell cuvette at a rate of 1.5 $\mathrm{mL} / \mathrm{min}$. The cuvette was placed in the laser beam and irradiated for $40 \mathrm{~min}$. After irradiation, the solution was brought to $200 \mathrm{mM} \mathrm{NaCl}$, ethanol-precipitated, washed, and dried. The DNA was loaded onto a $15 \% 8 \mathrm{M}$ urea denaturing polyacrylamide gel $(40 \mathrm{~cm} \times 40 \mathrm{~cm} \times 0.05 \mathrm{~cm})$ and electrophoresed at $45 \mathrm{~W}$ for $3 \mathrm{~h}$. The cross-link and the unmodified DNA bands were located by UV shadowing, excised, and electroeluted from the gel. The unmodified DNA and cross-link were finally ethanol-precipitated, washed, and dissolved each in $600 \mu \mathrm{L}$ of TE.

Preparation of Larger DNA Fragments Containing Photoadducted Spin-Label. A set of complementary 21-mer DNA oligomers that formed a helix of $17 \mathrm{bp}$ with a central $5^{\prime}-\mathrm{TpA}-3^{\prime}$ site and four base overhangs on each and were synthesized with an $E c o$ R1 restriction site and a BamH1 site on either end. The sequence is shown below.

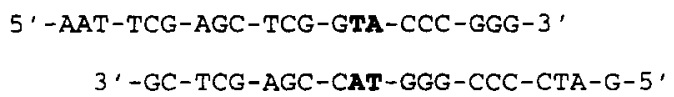

A solution of the two 21-mers and either psoralen 3 or 4 was irradiated in a flow cell using an argon ion laser emitting at $366 \mathrm{~nm}$ to form cross-linked molecules as described above.

Ligation of the Cross-Linked 21-mers and 25-mers. Higher molecular weight molecules of DNA containing the spin label were generated by kinasing the gel-purified crosslinked 21-mer oligonucleotides as above. The DNA strands were phenol-extracted-once with phenol, once with phenolchloroform, and once with chloroform-precipitated twice, and resuspended in $600 \mathrm{~mL}$ of $66 \mathrm{mM}$ Tris- $\mathrm{HCl}(\mathrm{pH} \mathrm{7.6),}$ $6.6 \mathrm{mM} \mathrm{MgCl}_{2}, 10 \mathrm{mM}$ DTT, $50 \mathrm{mg} / \mathrm{mL}$ BSA, $1 \mathrm{mM} \mathrm{ATP}$, and $4000 \mathrm{U} \mathrm{T} 4 \mathrm{DNA}$ ligase for $16 \mathrm{~h}$ at $16^{\circ} \mathrm{C}$. The reaction mixture was then adjusted to $200 \mathrm{mM} \mathrm{NaCl}$ and precipitated with ethanol. The precipitate was collected by centrifugation, washed, dried, and electrophoresed. Multimers of 1-8 of the linearly connected 21 -mer duplexes were isolated by electrophoresing on a $1 \mathrm{~mm} \times 40 \mathrm{~cm} \times 40 \mathrm{~cm}$ denaturing $8 \%$ polyacrylamide gel at $50 \mathrm{~W}$. The multimerized DNA bands were located by autoradiography, excised, and electroeluted from the gel. The individual multimerized crosslinked molecules were finally ethanol-precipitated, washed, and dissolved each in $10 \mu \mathrm{L}$ of TE. The 21 -mers proved to be poor substrates for DNA ligase, giving a low yield of the desired multimers, and only $50-60 \%$ of the oligomers and multimerized oligomers was recovered from the gels.

Klenow Reaction To Fill in the $5^{\prime}$-Overhanging Ends of the Multimerized 21-mers. The individual multimers isolated from the ligation reaction of the 21 -mer XL were dissolved in $20 \mu \mathrm{L}$ of Klenow reaction buffer $(40 \mathrm{mM}$ potassium phosphate (pH 7.5), $6.6 \mathrm{mM} \mathrm{MgCl}_{2}, 1 \mathrm{mM}$ DTT, $0.25 \mathrm{mM}$ each dCTP, dGTP, dTTP, and $40 \mu \mathrm{Ci} 600 \mathrm{Ci} / \mathrm{mmol}\left[\alpha-{ }^{32} \mathrm{P}\right]-$ dATP), and 10 units of the Klenow fragment of DNA polymerase. After $4 \mathrm{~h}$, the reaction mixture was diluted with 


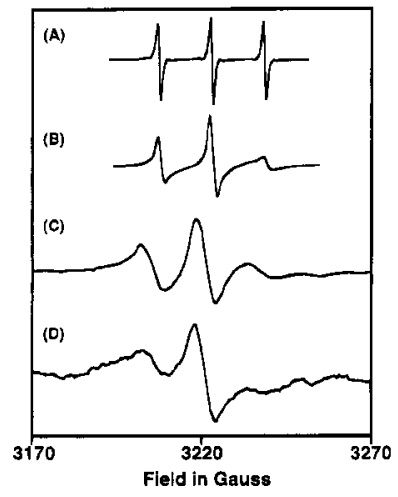

FIGURE 3: Experimental EPR spectra of (A) psoralen 3 in solution, (B) the cross-link formed between the 8-mer $5^{\prime}$-GGGTACCC-3' and psoralen 3, (C) the cross-link formed between a 25-mer DNA duplex and psoralen 3 , and (D) the cross-link formed between a 46-mer DA duplex and psoralen 3. Note the DNA length dependent broadening of the spectra.

$20 \mu \mathrm{L}$ of $10 \mathrm{M}$ urea, heat/cooled, and loaded onto a $12 \% 8$ $\mathrm{M}$ urea denaturing polyacrylamide gel. The filled-in multimerized DNA bands were located by autoradiography, excised, and electroeluted from the gel. The individual multimerized cross-linked molecules were finally ethanolprecipitated, washed, and dissolved each in $10 \mu \mathrm{L}$ of TE.

$E P R$ Spectra. Continuous wave X-band EPR spectra were obtained at room temperature at $9.2 \mathrm{GHz}$ using a Medical Advances loop-gap resonator. Signal averaging was utilized to obtain the spectrum of the $46 \mathrm{bp}$ cross-linked oligomer.

Modeling of Psoralen-DNA Complexes. Coordinates for the HMT-cross-linked DNA octamer d(GCGTACGC $)_{2}$ were obtained and formatted for use with the cff 91 force field. The spin-label side chains were created in the Builder module of Insight II (Biosym, San Diego). All of the spin-labels were modeled as the reduced hydroxylamine. The spin-label substituents were manually docked into the model of the XLDNA and the appropriate bonds formed. The resulting structures were then energy-minimized using the Discover (version 3.0) module of Insight II with conjugate gradients refinement to an rmsd of 0.01 . The coordinates of the molecule were held constant except for the spin-label, the psoralen, and the two covalently attached thymidines.

\section{RESULTS}

We synthesized six new spin-labeled psoralens and investigated their photochemical properties. We chose to continue our investigations into the dynamics of DNA with only one of them, psoralen 3 . From our molecular-modeling results, we believed that psoralens $6-8$ would cause additional interactions with the surrounding DNA, and they were excluded (see discussion). Of the three remaining psoralens which placed the spin label in the major groove, we proceeded with 3 because the nitroxide is in a ring with limited internal conformational freedom. EPR spectra have been obtained for DNA molecules of 8,25 , and 46 bp crosslinked with psoralen 3 (Figure 3 ). In all cases, the spectra can be interpreted to indicate that the nitroxide spin label reports the overall reorientation of the DNA with what appears to be bending and twisting modes and perhaps some residual motion (see below). Cross-linked and multimerized molecules of $67,88,109,130,151$, and 172 bp were also isolated; however, there was insufficient material available to acquire adequate EPR spectra.
Interpretation of EPR Spectra. The EPR spectra of the psoralen photobound to DNA were analyzed to determine how well the nitroxide reported on the overall motion of the DNA. We extracted rough rates of rotational reorientation from experimental EPR spectra by comparing them with simulated spectra. The results show that the photobound spin-labels reported the overall reorientation of the oligomers investigated. The rotational correlation time of a spherical molecule is given by

$$
\tau_{\mathrm{c}}=V_{\mathrm{h}} \eta / k T
$$

where $V_{\mathrm{h}}$ is the hydrated volume and $\eta$ is the viscosity of water.

Equation 1 gives only crude values for the expected rotational correlation times of the oligomers studied. The cross-linked spin-labeled oligomers are approximated poorly by spheres and will reorient with different rates about their major and minor principal axes. The DNA oligomers can be more accurately modeled as rigid cylinders where the volume of the hydrated DNA oligomers can be approximated with a varius of $10.7 \AA$ and a length of $3.4 N \AA$, where $N$ is the number of base pairs. The rates of orientational diffusion for such cylinders have been worked out with separate diffusion constants, $D_{\text {para }}$ and $D_{\text {perp }}$, for the two types of reorientation, parallel and perpendicular to the helix axis (Tirado \& Garcia de la Torre, 1979, 1980). A full analysis of the EPR spectra of molecules with anisotropic tumbling and internal bending and twisting motions has been performed for systems with good signal-to-noise (Spaltenstein et al., 1989). We used rotational correlation times calculated for spherical molecules to analyze our experimental results. A more detailed and accurate analysis based on anisotropic tumbling was not performed for the cross-linked DNA molecules in this preliminary study. The hydrated volumes for the spin-labeled molecules were calculated with the rigid cylinder formula. With these limitations in mind, we compared our experimental results to those generated by eq 1 .

The EPR spectra for spin-labeled psoralen 3 free in solution and for the self-complementary 8-mer 5'-GGTACCC- $3^{\prime}$ cross-linked with psoralen 3 are shown in Figure 3. The rotational correlation times for these two molecules were calculated by line height analysis to be $70 \mathrm{ps}$ and 2.5 ns, respectively (Likhtenstein, 1976). Compound $\mathbf{3}$ in solution gave a symmetric EPR spectrum characteristic of fast motion, and the cross-link formed between the octamer and compound 3 gave an EPR spectrum indicative of restricted slow motion of the spin bound in the doublestranded DNA helix. These compare with 150 ps calculated for a spherical molecule the size of $\mathbf{3}$ and 3 ns as given by eq 1 for the octamer DNA. We consider this acceptable agreement for the $\tau_{\mathrm{c}}$. These results indicate that the rotational freedom of the nitroxide reporter group covalently bound by cross-linking to the DNA is indeed limited by its interaction with the surrounding molecule.

The spectra that we acquired for molecules larger than the octamer cross-link were too complex to be analyzed by simple application of the line height equation. This result in and of itself indicates that the independent rotation and/ or reorientation of the nitroxide bound to the molecules was on a time scale longer than 3 ns. Experimental spectra were compared with simulated spectra generated by programs provided by Schneider and Freed (1989) to calculate rotational correlation times for the larger molecules. 


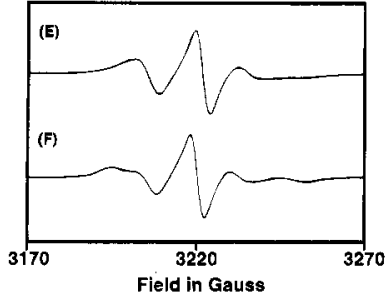

FIGURE 4: Calculated spectra that gave the best fit to the experimental spectra for $(E)$ the 25 -mer and $(F)$ the 46-mer. All simulated spectra were calculated using the parameters $g_{x x}=$ $2.00747, g_{y y}=2.00581, g_{z z}=2.00310, A_{x x}=6.24 \mathrm{G}, A_{y y}=10.05$ $\mathrm{G}$, and $A_{z z}=32.29 \mathrm{G}$, where the g-tensor couples the field $\mathrm{H}$ to the electron spin and the A-tensor couples the electron and nuclear spins (Schneider \& Freed, 1989).

The experimentally acquired spectra of the free psoralen 3 , the cross-linked octamer, 25-mer, and 46-mer cross-linked with psoralen 3 are shown in Figure 3. The 46-mer crosslinked with psoralen 3 has two psoralen cross-links per molecule separated by $21 \mathrm{bp}$. It is unlikely that the spins on any individual molecule would interact with each other, because the vast majority of the nitroxides in this sample were destroyed in the photochemical cross-link formation step (see below). The best simulated spectra for the 25 -mer and the 46-mer are shown in Figure 4. The best correlation time fit to the EPR spectrum of the 25-mer in Figure 3 gives a $\tau_{\mathrm{c}}$ of $5 \mathrm{~ns}$. Equation 1 gives a $\tau_{\mathrm{c}}$ of $9.5 \mathrm{~ns}$, but as noted, the approximation of isotropic rotation is very poor in this case. However, if the photobound spin labels are moving independently of the DNA, the amount of such motion is likely to be relatively small because the spectra show continued broadening with increasing size. The spectrum for a 10 times more concentrated solution of the 25 -mers (data not shown) best resembles a simulation with a $\tau_{c}$ of $6.7 \mathrm{~ns}$. The increase in the correlation time is probably due to intermolecular interactions in the more concentrated DNA solution. The spectra for the $46 \mathrm{bp}$ fragment are more problematic because of the combination of very low signalto-noise and the presence of a background signal in the EPR cavity. The 46 bp fragment data are consistent with simulations with a $\tau_{\mathrm{c}}$ of $8.3 \mathrm{~ns}$, as well as with simulations with a much longer $\tau_{\mathrm{c}}$, e.g. $16.7 \mathrm{~ns}$.

The two main reasons for the relatively poor fit of the experimental and calculated EPR spectra are the use of an isotropic model for the rotational diffusion and the fact that we explicitly did not take DNA bending and twisting motions into account. As shown by Hustedt et al., these motions will have a detectable effect on the spectra of the longer oligomers. Large scale internal fluctuations in the position of the psoralen coupled to the nitroxide may add additional modes that need to be accounted for in a full analysis of the spectra. In spite of these crude approximations in our analysis, the clear trend in the data is that of longer rotational correlation times that scale with the oligomer's molecular weight. The spectra would indicate reorientation rates for the molecules that were much smaller than theoretically expected for each oligomer's molecular weight if rapid large scale motions of the psoralen cross-link were present independent of the overall tumbling. We can therefore infer that, if our spin-labels are moving independently of the DNA, the amplitudes of such motions are not large.

Synthesis. We have synthesized two sets of compounds that have spin-label (nitroxide) reporter groups attached to
Scheme 1

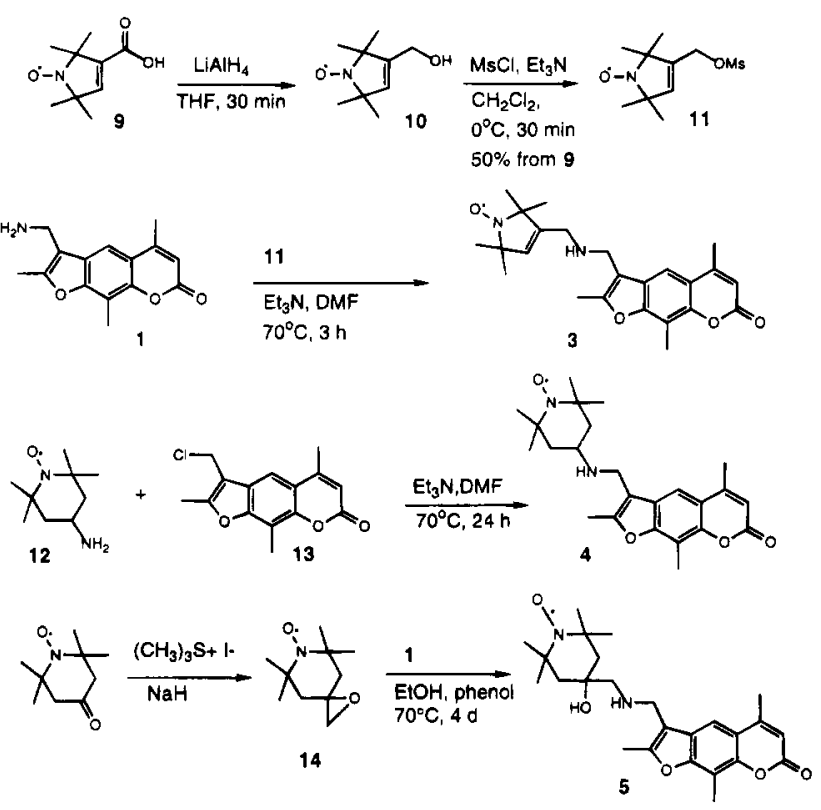

Scheme 2

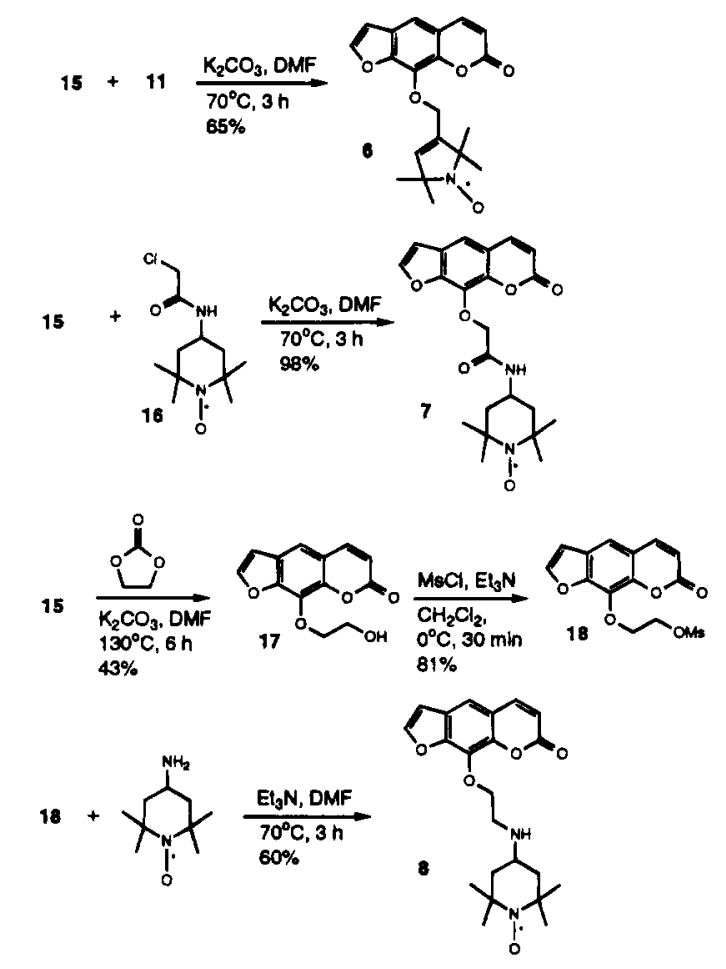

the psoralen via single bonds that act as electronic insulators of the spin-label from the psoralen nucleus. One set is AMT (4'-(aminomethyl)-4,5',8-trimethylpsoralen) derivatives and $3-5$, and the other set is 8-MOP (8-methoxypsoralen) derivatives and $\mathbf{6}-\mathbf{8}$.

The syntheses of the six spin-labeled psoralen derivatives are shown in Schemes 1 and 2. Mesylpyrrolinyl nitroxide 11 was prepared from carboxylic acid 9 by reduction (Rauckman \& Rosen, 1976a) and mesylation in 50\% overall yield. The displacement reaction of mesyl nitroxide by AMT in DMF ( $N, N$-dimethylformamide) at $70^{\circ} \mathrm{C}$ for $3 \mathrm{~h}$ provided spin-labeled AMT derivative 3 in 55\% yield. Similarly, derivative 4 was prepared from TEMPAMINE 12 and $4^{\prime}-$ (chloromethyl)-4, $5^{\prime}, 8$-trimethylpsoralen (CMT, 13) in $80 \%$ 
Table 1: Amount of Cross-Link Formation between the Double-Stranded 8-mer 5'-GGGTACCC-3' and the Six Spin-Labeled Psoralen Derivatives and Controls ${ }^{a}$

\begin{tabular}{lc}
\hline psoralen & \% cross-link \\
\hline $\mathbf{3}$ & 13 \\
$\mathbf{4}$ & 9 \\
$\mathbf{5}$ & 23 \\
$\mathbf{6}$ & 9 \\
$\mathbf{7}$ & 31 \\
$\mathbf{8}$ & 44 \\
HMT & 53 \\
AMT & 43 \\
8-MOP & 38 \\
\hline
\end{tabular}

${ }^{a}$ Each reaction was performed by irradiating a $50 \mu \mathrm{L}$ volume containing $10 \mu \mathrm{g} / \mathrm{mL}$ of the appropriate psoralen, $10 \mathrm{ng}$ of $5^{\prime}-{ }^{32} \mathrm{P}$-labeled 5'-GGGTACCC-3', $150 \mathrm{mM} \mathrm{NaCl}, 10 \mathrm{mM} \mathrm{MgCl}_{2}$, and $10 \mathrm{mM}$ Tris$\mathrm{HCl}\left(\mathrm{pH} 7.5\right.$ ) for $10 \mathrm{~min}$ with $300 \mathrm{~mW} / \mathrm{cm}^{2} 320-380 \mathrm{~nm}$ light. The DNA was isolated by ethanol precipitation, and the cross-linked species were separated by electrophoresis on a $20 \%$ denaturing polyacrylamide gel. The unmodified DNA and the bands that contained the crosslinks were located by autoradiography, excised, and counted with fluor in a scintillation counter.

yield. Epoxide 14 [in Rauckman et al. (1976b)] was slowly ring-opened by AMT in the presence of phenol at $70{ }^{\circ} \mathrm{C}$, giving (hydroxyamino)psoralen in 50\% yield. 8 -Hydroxypsoralen (15) was prepared from 8-MOP by demethylation with $\mathrm{BBr}_{3}$ (57\%; Isaacs et al., 1982). The displacement reaction of mesylpyrrolinyl nitroxide $\mathbf{1 1}$ by the phenoxide of 15 in DMF at $70^{\circ} \mathrm{C}$ for $3 \mathrm{~h}$ gave spin-labeled 8-MOP derivative 6 in good yield. Amido-8-MOP compound 7 was prepared in a similar manner to that of $\mathbf{6}$ from 8-hydroxypsoralen and TEMPO chloroacetamide in high yield (98\%). Spin-labeled 2-(aminoethoxy)psoralen (8) was synthesized by displacement reaction from corresponding mesylate $\mathbf{1 8}$ and TEMPAMINE 12. Treatment of a mixture of 8-hydroxypsoralen and ethylene carbonate with base provided the precursor alcohol 17 of mesylate 18.

Photoreactivity of Spin-Labeled Psoralens with DoubleStranded DNA. Spin-labeled psoralens 3-8 were irradiated in the presence of the double-stranded DNA oligonucleotide $5^{\prime}$-GGGTACCC-3' (8-mer) containing a central 5'-TpA site that is especially reactive toward psoralen photo-cross-linking (Gamper et al., 1984). Table 1 shows the results for the XL formation between the double-stranded 8-mer and the six spin-labeled spin-labeled psoralen derivatives, 8-MOP, AMT, and HMT. Five of the six new psoralen derivatives (excepting 8) react to form lower levels of XL than 8-MOP, AMT, and HMT.

An attempt was made to form only the furansidemonoadducted oligonucleotide of psoralen 3 without conversion to XL by irradiation with $389 \mathrm{~nm}$ light (Chatterjee \& Cantor, 1978; Spielmann et al., 1992). MAf is formed preferentially to XL under these conditions with HMT and AMT. Only cross-linked molecules resulted from the reaction between the DNA and 3 .

The distribution of furanside monoadducts and cross-links in a photoreaction will depend on the rate of MAf formation relative to the rate at which the monoadduct goes on to XL. These results can be rationalized if the quantum yield for the conversion of the intercalated noncovalent complex of 3 to MAf is much smaller the quantum yield for the subsequent conversion to XL at this wavelength (Spielmann et al., 1992).

The bulk of the spin-label group attached to the $4^{\prime}$-position of the psoralen appears to interfere with the initial intercala- tion geometry, slowing the rate of monoaddition, but once a MAf is formed, cross-linking proceeds normally. Of psoralens $\mathbf{3 - 5}$, the longer the linker between the psoralen nucleus and the spin-label, the better the photoreactivity, in the order $\mathbf{4}, \mathbf{3}, \mathbf{5}$. A similar pattern is seen with compounds 6-8. We have also found that psoralens with substituents at the 8-position are more reactive than those with substituents at the $4^{\prime}$-position. For this reason, compound 6 has the same reactivity as compound 4 , even though it is uncharged and extremely insoluble in water. Aliphatic amino substituents on the psoralens greatly increase their solubility in water and their affinity for the negatively charged phosphates of the DNA backbone because they are positively charged in aqueous solution at neutral pH (Isaacs et al., 1977).

Photochemical Characterization of the Psoralens. The distribution and behavior of the photochemical adducts formed with the spin-labeled psoralens were further characterized and compared with those of the parent molecules, AMT and 8-MOP. Both the forward and reverse photochemical addition reactions are of interest, because the entire family of psoralen adducts can be generated in this way (Cimino et al., 1985). The forward reaction proceeds by intercalation followed by photoconversion to either the MAf or the MAp. Only the MAf can continue on to form crosslink (XL) by irradiation with UV-A. Photoreversal of AMT-, HMT-, and 8-MOP-cross-linked molecules gives both the MAf and the MAp. The reaction products from the reversal of the cross-link as well as the monoadducts can be conveniently monitored by polyacrylamide gel electrophoresis (PAGE) of the modified DNA (Gamper et al., 1984). The mobility of psoralen-cross-linked DNA molecules on denaturing PAGE is much lower than that of unmodified species. The mobility of psoralen-monoadducted species is also retarded relative to that of unmodified DNA, but not nearly as much as by XL. Figure 7 is an autoradiogram of crosslink reactions between the self-complementary DNA oligomer $5^{\prime}$-GGGTACCC-3' and the six spin labels 3-8. All of the new psoralens $\mathbf{3}-\mathbf{8}$ formed photoadducts with the DNA that are consistent with cross-linked and monoadducted species. The differences in product distributions for the new psoralens relative to the parent AMT and 8-MOP are probably due to subtle changes in the relative binding constants and noncovalent intercalation geometry brought about by the spin-labeled substituents. Figure 8 is an autoradiogram of the photoreversal of the major bands that corresponded to cross-links for psoralens $\mathbf{3 - 5}$, and Figure 9 is an autoradiogram of the photoreversal of the major bands that corresponded to cross-links for psoralens 6-8. The photoreversal of psoralen cross-links to unmodified DNA is a two-photon process. The intermediate products are either the furan- of pyroneside monoadducts. The rate of photoreversal of cross-links to monoadducts is faster than the rate of photoreversal of monoadducts to unmodified DNA because monoadducted DNAs are observed after irradiation of the cross-linked molecules with $254 \mathrm{~nm}$ light (Gamper et al., 1984). Examination of the autoradiograms leads us to conclude that the photochemical behavior of the new psoralens follows the same general patterns as the behavior of AMT, HMT, and 8-MOP. Multiple products in the crosslinked bands are due to the simultaneous presence of monoadducts and cross-links in the upper bands and ringopened and ring-closed isomers of the pyroneside of the 

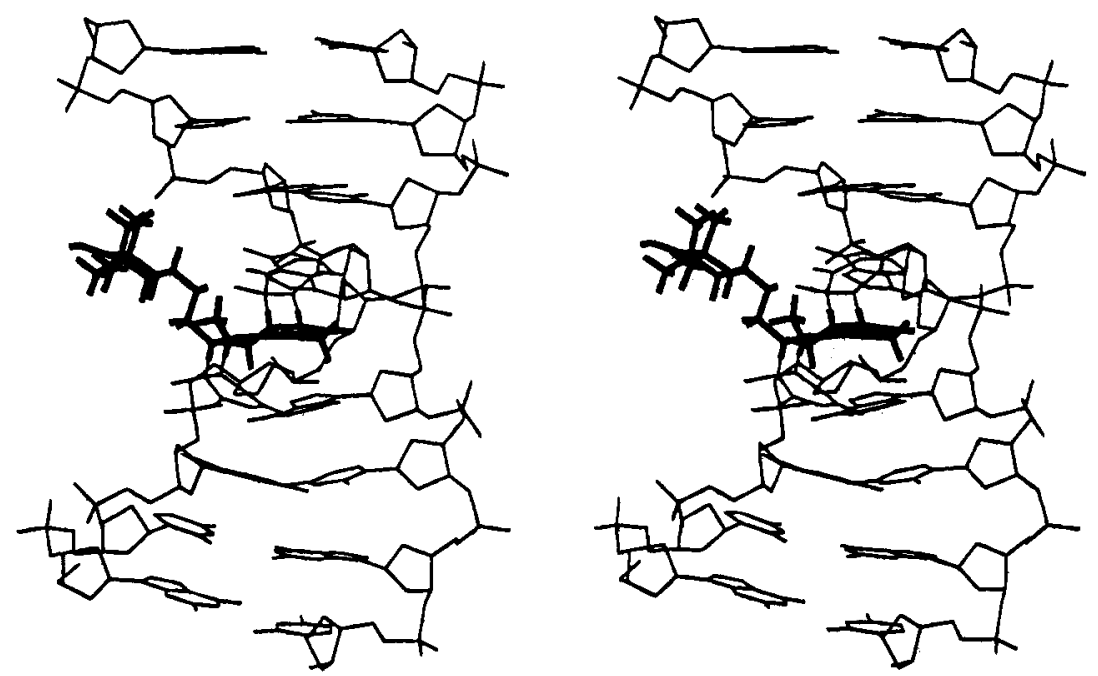

FIGURE 5: Stereoview of a molecular model of the psoralen 4-DNA cross-link of d(GCGTACGC $)_{2}$ obtained by energy minimization as described in the text. For clarity, hydrogen atoms are omitted for the DNA model but not for the psoralen.
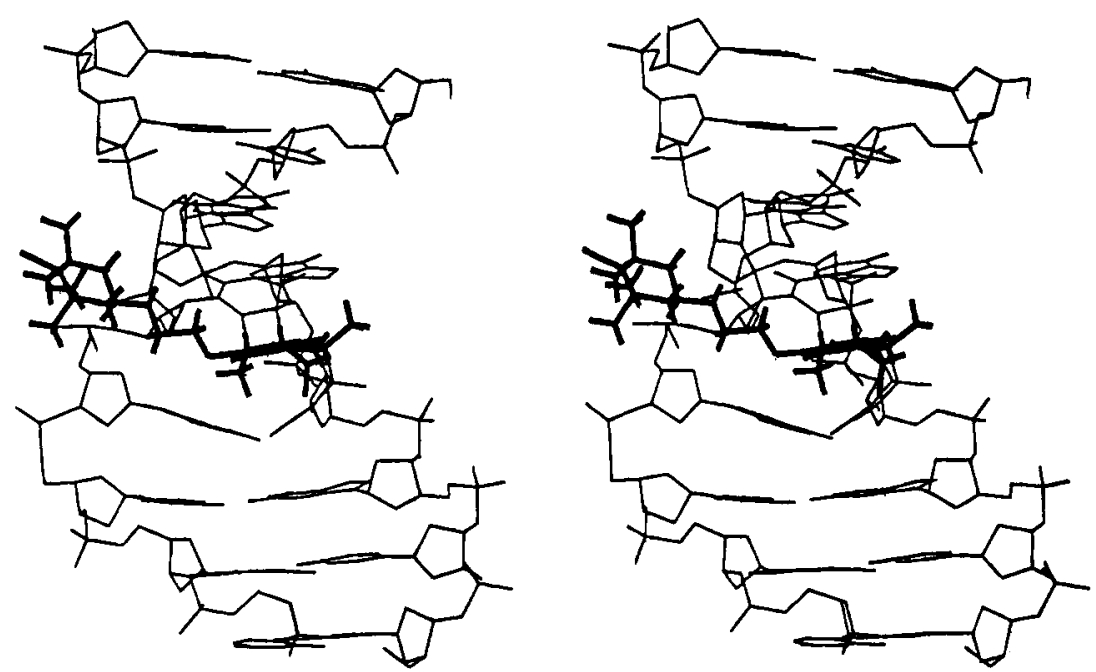

FIGURE 6: Stereoview of a molecular model of the psoralen 8-DNA cross-link of d(GCGTACGC) ${ }_{2}$ obtained by energy minimization as described in the text. For clarity, hydrogen atoms are omitted for the DNA model but not for the psoralen.

cross-links (Cimino et al., 1986). The lower cross-linked band corresponds to a single cross-link adduct. Although the primary site for photoreaction in DNA is thymidine, cytosine can also react to form adducts. The multiple monoadduct bands are probably due to thymidine and cytosine furan- and pyroside adducts.

The uppermost of the three crosslink bands formed by photoreaction with psoralen 3 and the lowermost of the three cross-link bands are identical material (Figure 8, compare lanes 2 and 6) that photoreverse to two bands that correspond to monoadducts and the unmodified DNA (Figure 8, compare lanes 1 and 5). These two XL bands are due to the presence of pyrone ring-closed and ring-open forms of the cross-link. Lane 3 in Figure 8 is the photoreversal reaction of the middle band formed by photoreaction with psoralen 3 , which gives products that correspond to the presence of multiple psoralen adducts. A similar pattern for the photoreversal of psoralens 4 and 5 is also observed (Figure 8), and for psoralens $6-8$ (Figure 9).

Photochemistry of the Nitroxide. EPR spectra of the individual multimerized cross-linked oligomers were acquired. A minimum of $10^{14}$ spins is necessary in order to acquire a good EPR signal. This is approximately $3 \mu \mathrm{g}$ of cross-linked DNA 21, assuming all of the monomers contained a spin-label. Much larger quantities than this of each of the 1-4 multimers of the 21-mer duplexes were synthesized. All of the molecules isolated were cross-linked with the spin-labeled psoralen. However, very little EPR signal was observed, and this was ascribed to the photodestruction of the spin-label by the intense laser light. Only $5 \%$ of the gel-isolated cross-linked molecules had intact spinlabels. Nitroxides have a weak absorption at $410 \mathrm{~nm}$ and can undergo photoreduction to the hydroxylamine, photoaddition insertion reactions, and, in the case of 1-oxy-2,2,5,5tetramethyl-3-pyrroline, the photoextrusion of nitric oxide (NO) (Keana, 1978). No degradation of the EPR signal was observed when the spin-labeled psoralens or the various nitroxides used to synthesize 3-8 were irradiated with 366 $\mathrm{nm}$ laser light in aqueous solution for $5 \mathrm{~min}$ (data not shown). Most of the EPR signal was destroyed when the psoralen was cross-linked into the DNA. Attempts to reoxidize the nitroxide of $\mathbf{4}$ cross-linked into DNA molecules of various lengths using cupric acetate failed (Keana et al., 1975). if the psoralen-DNA-spin-label complex was simply photoreduced, copper-catalyzed reoxidation of the nitroxide should have been possible. If the nitroxide had photoinserted 

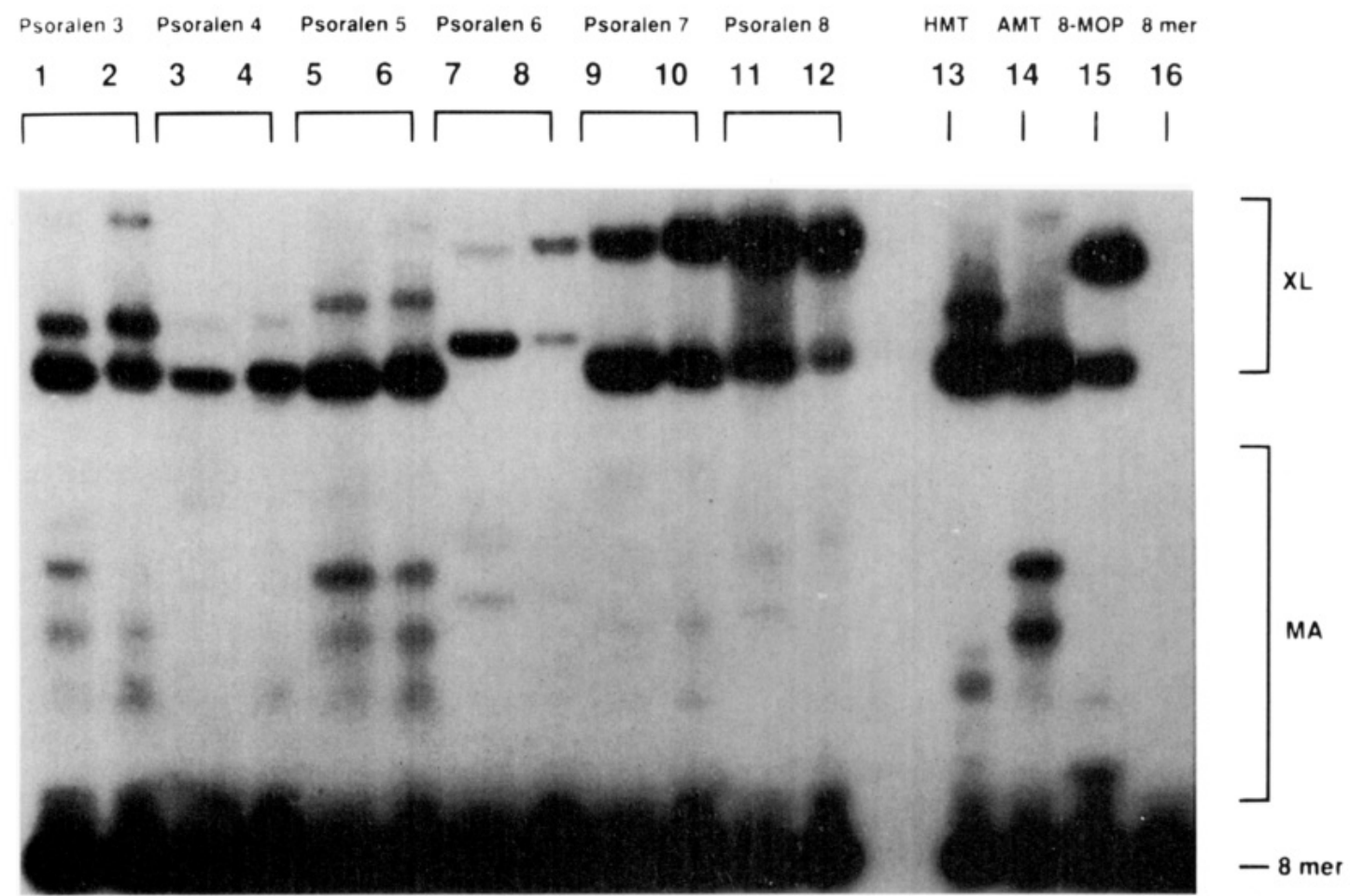

FIGURE 7: Shown is an autoradiogram of cross-link reactions between the self-complementary DNA oligomer $5^{\prime}$-GGGTACCC-3' and the six spin-labels 3-8 (structures in Figure 1). Lanes 1-12 are cross-linking reactions with the psoralens $\mathbf{3}-\mathbf{8}$ in pairs. The first lane in each pair is one addition of the psoralen followed by irradiation for $5 \mathrm{~min}$ with light transmitted through a $\mathrm{Co}\left(\mathrm{NO}_{3}\right)_{2}$ band-pass filter $(300 \mathrm{~mW}$ by uranium oxalate actinometry), and the second lane in each pair is a second addition of the psoralen followed by irradiation for an additional $5 \mathrm{~min}$. Lane 13 is reaction with one addition of HMT. Lane 14 is reaction with AMT. Lane 15 is reaction with 8-MOP. Lane 16 is the DNA.

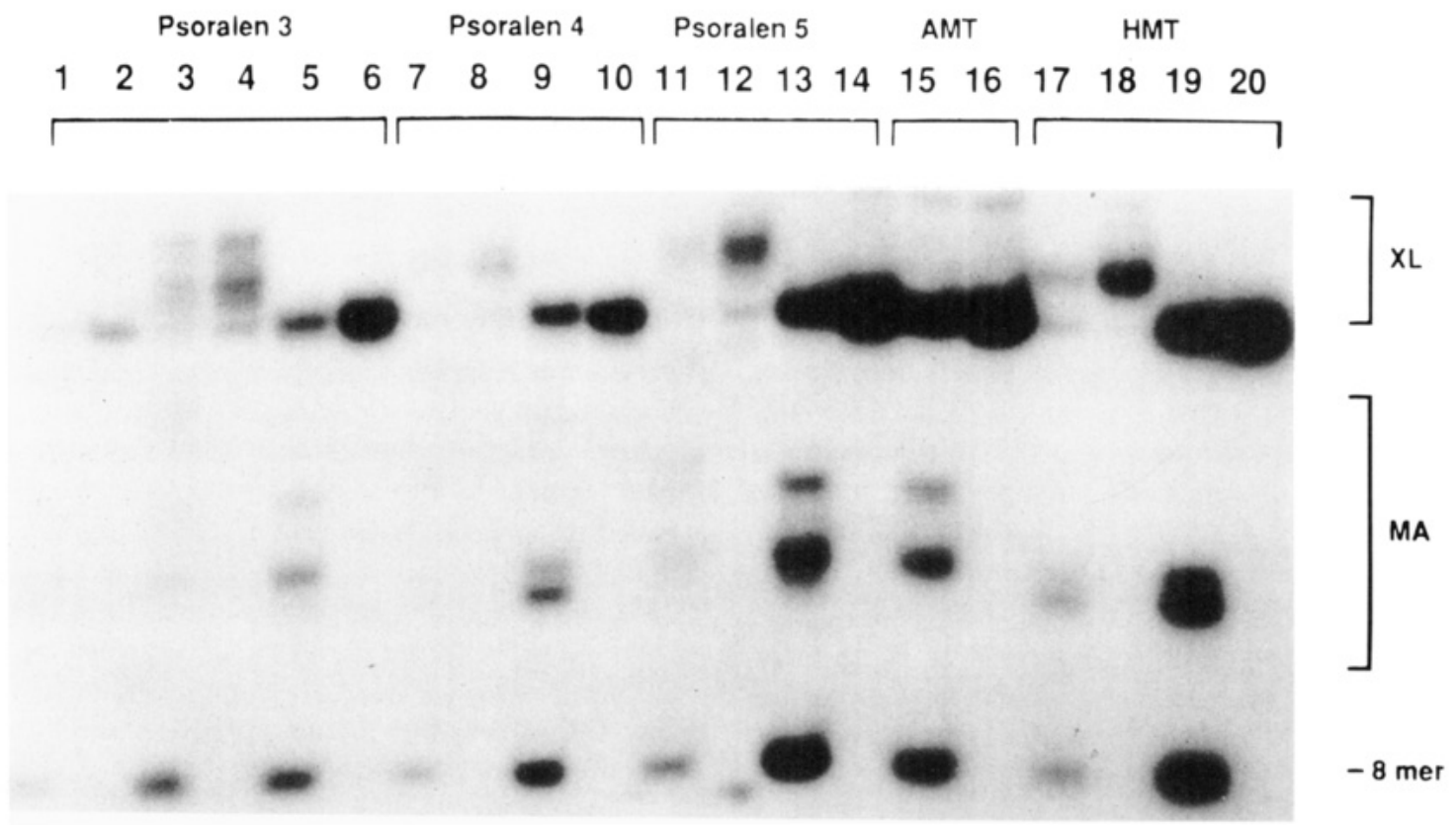

FIGURE 8: Shown is an autoradiogram of the photoreversal of the major cross-link bands for psoralens $\mathbf{3}-\mathbf{5}$ in pairs. The first lane in each pair is the cross-link oligomer photoproduct photoreversed with $254 \mathrm{~nm}$ light, and the second is the parent material. Lanes 15 and 16 are the reference reaction of the AMT cross-link, and lanes 17-20 are photoreversal reactions of two different HMT cross-links. Reversal of the AMT cross-links gives two monoadducts and the unmodified DNA. The upper HMT cross-link in lanes 17 and 18 is from a cross-link plus a monoadduct in the same molecule and gives two monoadducts: the unmodified DNA and the lower cross-link (lane 20). Lane 19 is the photoreversal of the lower HMT cross-link, and it gives two monoadducts and the unmodified DNA.

itself into the surrounding DNA molecule or had undergone the photoextrusion of NO, no reoxidation and recovery of the EPR signal would have been possible. Potential strategies for overcoming the problem of photochemical destruction of the nitroxide are (1) to do the photoreaction with reduced spin-labeled psoralen followed by reoxidation of the cross-linked molecules, (2) the use of longer wavelength light to drive the photochemistry, and/or (3) a reduction in the intensity of the cross-linking light. The light from the argon ion laser had an intensity of approximately $25 \mathrm{~W} / \mathrm{cm}^{2}$ which 

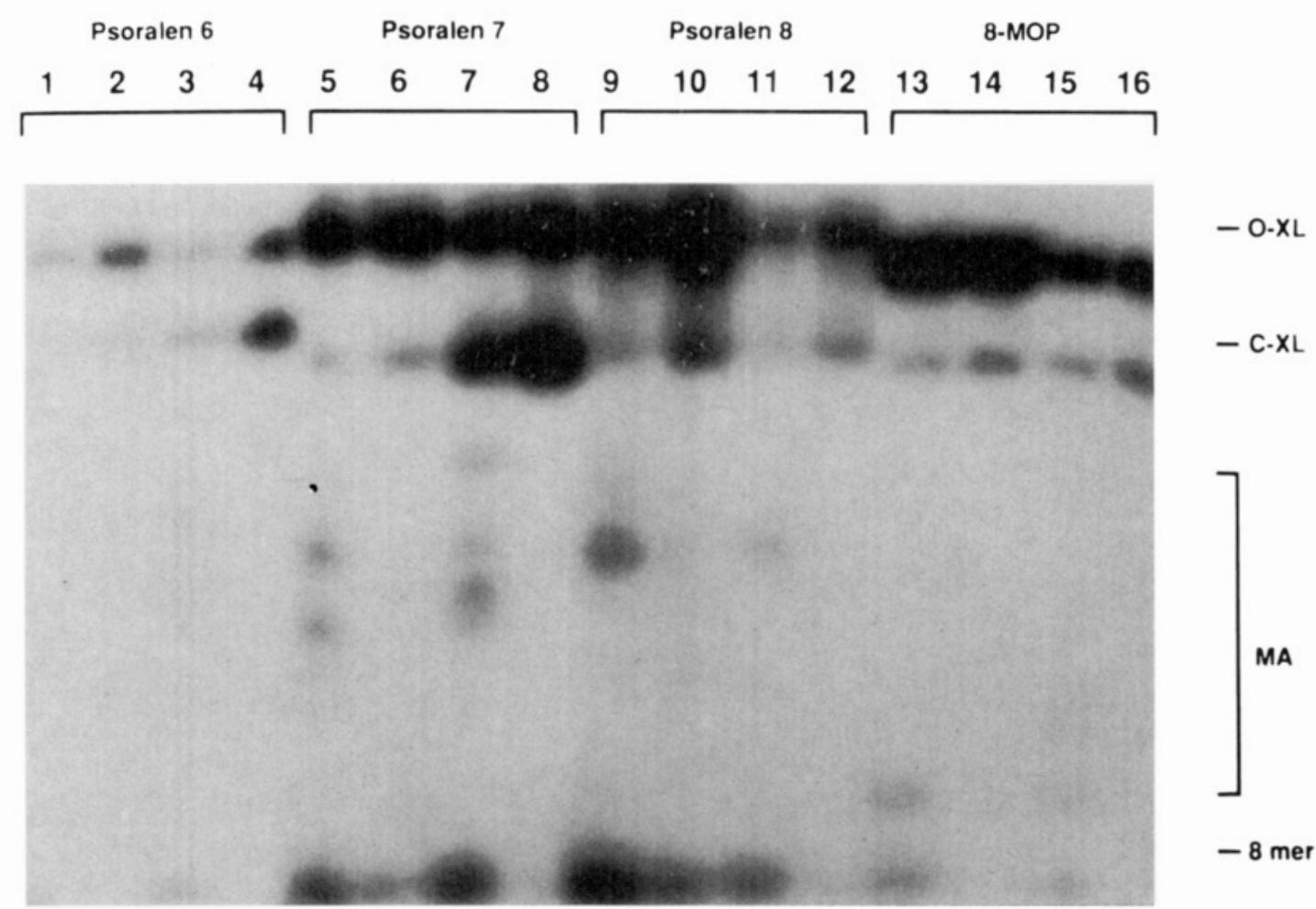

FIGURE 9: Shown is an autoradiogram of the photoreversal of the major cross-link bands for psoralens $\mathbf{6}-\mathbf{8}$ in pairs. The first lane in each pair is cross-linked oligomer photoproduct photoreversed with $254 \mathrm{~nm}$ light, and the second lane in each pair is the parent material. Lanes 13-16 are photoreversal reactions of the two 8-MOP cross links. Lane 13 is photoreversal of the upper 8-MOP cross-link, and lane 15 is the photoreversal of the lower 8-MOP cross-link. Both give two monoadducts and the unmodified DNA with identical electrophoretic mobility. The different mobilities of the two products in the initial gel are due to the ring-open and ring-closed forms of the pyrone side of the cross-link.

is 100 times the intensity of the light source used to investigate the photo-cross-linking of the 8-mer d(GGGTACCC $)_{2}{ }^{2}$

\section{DISCUSSION}

We have described here the synthesis of several spinlabeled psoralen derivatives and their photoreactivity with double-stranded DNA fragments. The EPR spectra that were acquired indicate that the spin-labels report the overall tumbling of the DNA oligomers and do not give any obvious indication of major large amplitude mobility of the adducts relative to the overall reorientation of the molecule.

Design Considerations for the Synthesis of Spin-Labeled Psoralens. In this study, we make use of the wellcharacterized photochemistry of psoralen with nucleic acids to covalently attach spin-labels at sequence specific sites. Short linkers between the spin-label and the psoralen nucleus were chosen to inhibit the independent motion of the reporter group. The structure of the oligonucleotide d(GCGTACGC) cross-linked at the central 5'-TpA-3' site with HMT derived from a 2-D 'H NMR study (Spielmann et al., 1995) was used to predict the interactions of the spin-label with the appropriate spin-label moiety to give models of compounds 3-5. The 8-methyl group was replaced with the appropriate linker arm and spin-label to model compounds $\mathbf{6}-\mathbf{8}$. The energy of the models was then minimized for the spin-label

${ }^{2}$ A further experimental difficulty encountered was the destruction of the EPR signal over time after the DNA had been introduced into the sample tubes and sealed with a silicon-based vacuum grease. We found that TEMPONE in aqueous Tris buffer was destroyed by the vacuum grease with a half-life of $11 \mathrm{~h}$. relative to the DNA while holding the coordinates of the DNA fixed. Figure 5 is a stereoview of the model of the DNA 8-mer d(GCGTACGC) ${ }_{2}$ cross-linked at the central 5'TpA-3' site with psoralen $\mathbf{4}$ as a representation of the spinlabel in the major groove. Inspection of these models led us to conclude that attachment of the relatively bulky spinlabels to the $4^{\prime}$-position of the psoralen would not introduce any dramatic steric clashes with the surrounding DNA. Figure 6 is a stereoview of the model of the DNA 8-mer $\mathrm{d}(\text { GCGTACGC })_{2}$ cross-linked at the central 5'-TpA-3' site with psoralen $\mathbf{8}$ where the spin-label is in the minor groove. Free motion of the spin-labeled side chain appears to be hindered by many steric interactions between the spin-labeled ring and the surrounding DNA, most notably with the deoxyribose residues that make up the walls of the minor groove. Additional DNA structural perturbations beyond those found for the parent psoralen are expected from the 8-nitroxidesubstituted molecules because of these interactions.

Psoralens $\mathbf{3}-\mathbf{5}$ do not eliminate the possibility of nitroxide motion independent of the psoralen cross-link. While the five-membered, unsaturated, nitroxide-bearing ring of $\mathbf{3}$ is expected to have only slight internal conformational mobility, rotation of the ring about the four $\sigma$-bonds linking the spinlabel to the psoralen is still possible. The six-membered nitroxide rings of $\mathbf{4}$ and $\mathbf{5}$ are expected to have slightly greater internal mobility than $\mathbf{3}$, but they only have three $\sigma$-bonds connecting the spin-label to the psoralen in 4 . The sixmembered nitroxide ring of $\mathbf{5}$ is connected by four $\sigma$-bonds to the psoralen where there is the possibility of conformational restriction because of internal hydrogen bond formation between the amine and the hydroxyl group. 
Ideally, the nitroxide spin-label would be attached to the psoralen in such a fashion that it is incapable of any motion which is independent of the motion of the psoralen. Rotation about double bonds where the spin-label group is conjugated to the psoralen $\pi$-system would be hindered. Unfortunately, functional groups that conjugate with the $\pi$-system of the psoralen nucleus dramatically decrease the photoreactivity of the compound, and in most cases, the reactivity toward nucleic acids is eliminated (Cimino et al., 1985).

Implications for DNA Repair. Recognition of damaged DNA by the $(\mathrm{A}) \mathrm{BC}$ excinuclease repair system is initiated by the binding of the $\operatorname{UvrA}_{2} \mathrm{~B}_{1}$ complex to the damage site. The $U_{v r} A_{2} B_{1}$ protein complex, utilizing energy provided by its ATPase activity, sharply bends the DNA into the major groove at the 11 th phosphodiester bond $5^{\prime}$ to the lesion, leaving the UvrB component tightly bound to the DNA. The molecular matchmaker UvrA then dissociates from the complex. In the absence of UvrA, UvrB appears to have no affinity for DNA. The (A)BC excinuclease repair system efficiently recognizes and removes psoralen damage from DNA. Understanding how the repair complex recognizes this class of lesions would allow us to understand how lesions in general are recognized by the repair system. The enzyme system must be able to detect structural or dynamic features of the DNA that distinguish between damaged and undamaged DNA and are independent of the intrinsic structure of the lesion.

NMR data suggest that the sugar-phosphate backbone of HMT-monoadducted and cross-linked DNA undergoes dynamic conformational changes relative to that of undamaged DNA (Emsley et al., 1993; Spielmann et al., 1995). It is unknown whether the adjacent adenine bases around the cross-link have altered dynamic properties, although their sugars do. The covalent geometry of the psoralen crosslink limits the possible conformations available to the DNA. The EPR data can be interpreted to suggest that there are no major excess motions of the psoralen with respect to the overall reorientation of the molecule. We suggest that the altered and more complex range of conformations in the deoxyribose backbone which have been observed by 2-D NMR are a potential signal for recognition of a lesion to be repaired. We suggest that the signal is in the sugarphosphate backbone, not in the damaged base(s). This stands to reason, because the excision repair system operates in a sequence neutral context. The DNA helix can be operationally divided in this model into the deoxyribose-phosphate backbone scaffold and the information-carrying bases.

The precise molecular features of DNA damage that the (A) $B C$ excinuclease repair system could recognize include (1) a greater propensity to bend or flex at the site of damage, (2) destabilization of the DNA in the region of the adduct, allowing it to more easily denature, or (3) a backbone with greater flexibility near the site of damage that can be more easily deformed by a scanning enzyme.

Bending of psoralen-cross-linked DNA has been observed by electron microscopic examination (EM) and has been explained in terms of increased flexibility of the DNA at the site of an XL adduct (Shi et al., 1988). However, a rigid bend in psoralen-monoadducted DNA was not observed under the same conditions by gel electrophoresis retardation analysis. NMR studies have shown that the helix axes of the XL and the MAf are both unbent. A number of other
DNA lesion-producing compounds that are recognized and repaired by (A)BC excinuclease do provoke bends in the helix axis at the site of damage, and others do not. In addition, there are natural motifs present in DNA such as A-tracts that are naturally bent and are ignored by repair systems. Therefore, we conclude that there is no correlation of DNA bending at the site of damage with recognition by (A)BC excinuclease.

Recognition of binding sites by DNA binding proteins such as 434 repressor, Cro, CAP, and other protein-DNA complexes has been proposed to be achieved by the sequence specific deformability of DNA (Drew \& Travers, 1985; Crothers et al., 1988; Koudelka et al., 1988; Satchwell et al., 1986; Schultz et al., 1991). The bend in the DNA under consideration must be interpreted with respect to the location, magnitude, and direction of the bend introduced by the UvrB-DNA complex. The DNA in the UvrB-DNA complex is proposed to be kinked sharply by $130^{\circ}$ into the major groove at the 11 th phosphodiester bond $5^{\prime}$ to the lesion (Shi et al., 1992). In contrast, the wedge model of A-tract bending is that the bend introduced into DNA by A-tracts is smoothly distributed over the tract and into the minor groove. None of the DNA-damaging agents produces increased susceptibility to bending that is $10 \mathrm{bp}$ removed from the site of damage. It is unlikely that a test for bendability at the site of the lesion (deformation of the helix axis) is being performed by the Uvr $\mathrm{A}_{2} \mathrm{~B}_{1}$ complex when it scans the DNA for damage.

The psoralen XL stabilizes the helix to denaturation by covalently linking the two strands, and the intercalated psoralen MAf stabilizes the helix by $1.3 \mathrm{kcal} / \mathrm{mol}$ (Shi \& Hearst, 1986). On the other hand, the presence of an exocyclic 1, $N^{2}$-propanodeoxyguanosine lesion, (Plum et al., 1992) an 2-(acetylamino)fluorene (AAF) adduct, (Garcia et al., 1993) or a thymine glycol (Kao et al., 1993) lowers the thermal stability of duplex DNA. The (A)BC excinuclease repair system recognizes and removes all of these adducts. If the repair systems were scanning for altered thermodynamic stability of the DNA helix to find damage, it is unlikely that both the increased and decreased stability of the helix are the determining factors for lesion recognition.

Under certain circumstances, noncovalent intercalators such as ditercalinium can induce "futile" repair, where undamaged DNA is excised and "repaired" (Lambert et al., 1990; Gao et al., 1991; Selby \& Sancar, 1991). These intercalators elongate and stiffen the DNA. It appears that ditercalinium causes a localized instability in the helix. This has led to the hypothesis that the $(\mathrm{A}) \mathrm{BC}$ excinuclease repair system recognizes excessive or unusual deformability of DNA (Williams \& Gao, 1992). It has been proposed that destabilization of stacking interactions contributes to the destabilization of the DNA which leads to the distortion of the DNA in the vicinity of the lesion, ultimately allowing for the wrapping of the DNA around UvrB.

NMR studies have shown that both the XL and MAf have altered backbone dynamics in the immediate vicinity of the adduct. The coupled "crankshaft motions" of the phosphate backbone and motion of the bases related to the dynamic conformational changes in the deoxyribose observed in the XL may be recognized as a signal by the DNA repair systems to locate DNA damage. The current study shows that there are no extraordinary base motions for the adducted thymidine 
residues in the XL to be recognized by the repair enzymes. Cellular repair systems recognize other DNA oligomers covalently modified with drugs that have radically different structures from the MAf and the XL that also show evidence of altered helix dynamics by NMR. The adduct between guanosine and $\mathrm{N}$-acetyl- $\mathrm{N}$-acetoxyaminofluorene has been shown by NMR to have multiple conformations and significantly different dynamic properties than unmodified DNA (O'Handley et al., 1993). The DNA repair system in this model recognizes changes in the equilibrium behavior of the DNA surrounding the adduct and not any specific structural features induced by the damage (Lin \& Sancar, 1989; Pu et al., 1989). We propose that the repair enzymes target lesions by detecting a change in the normal conformational flexibility of the sugar-phosphate backbone induced by DNA-damaging agents. There are numerous amino acid contacts to the backbone phosphates observed in hig-resolution X-ray crystal structure of protein-DNA complexes (Beamer \& Pabo, 1992). The flexibility of the phosphate esters in the recognition and formation of protein-DNA contacts has been proposed as a mechanism for discrimination of different operator sites by the lac repressor (Karslake et al., 1992; Botuyan et al., 1993). Flexibility of the backbone is a more general case of localized sequence-specific conformational variations in DNA that are potentially recognized by proteins. We propose the following two-step model for DNA lesion recognition and formation of competent excinuclease complex. The $\mathrm{Uvr}_{2} \mathrm{~B}_{1}$ complex scans the DNA for damage in an ATP independent process (Reardon et al., 1993). Normal, undamaged DNA backbone has a certain stiffness (firmness) that is recognized as undamaged by the $\mathrm{UvrA}_{2} \mathrm{~B}_{1}$ system. Introduction of a region of greater conformational freedom (softness) into the DNA backbone at the adduct is recognized as damage by the $\operatorname{Uvr}_{2} \mathrm{~B}_{1}$ complex. Determination of the precise backbone dynamic modes that are changed by lesion formation will require other experiments such as the measurement of order parameters and mutually exclusive coupling constants for the sugar residues by NMR.

The recognition of the lesion by the $\mathrm{UvrA}_{2} \mathrm{~B}_{1}$ complex and the subsequent bending of the DNA by UvrB are separate, sequential, linked events in this model. It has been proposed that an increased deformability of the DNA allows for kinetic trapping of the UvrB complex. However, the recognition of a lesion and the subsequent bending of the DNA around UvrB may be uncoupled. With the expenditure of ATP, any DNA sequence could be bent around the protein, obviating the need for a more highly distortable DNA. We propose that the UvrA component of the repair system recognizes that the backbone in damaged DNA is locally modified in its populations of unusual conformations which are manifested by observable changes in helix dynamics, with or without an increase in helix bendability. The subsequent steps in the repair mechanism are ATP driven, and the propensity for the DNA to bend at the site of the damage may be irrelevant.

In conclusion, the psoralen EPR probes measure the overall tumbling of the cross-linked molecules. These results suggest that DNA lesions made with other spin-labeleddamaging molecules and NMR experiments that look directly at the geometry and dynamics of the backbone be used to ascertain the conformational states that are recognized by the excision repair complex.

\section{ACKNOWLEDGMENT}

We thank Professor A. Sancar for helpful discussions and for his constructive criticism of the manuscript.

\section{REFERENCES}

Beamer, L. J., \& Pabo, C. O. (1992) J. Mol. Biol. 227, 177-196.

Bobst, A. M. (1979) in Spin Labeling, Vol II. Theory and Applications, pp 291-345, Academic Press, New York.

Bobst, A. M., Kao, S.-C., Toppin, R. C., Ireland, J. C., \& Thomas, I. E. (1984) J. Mol. Biol. 173, 63-72.

Borer, P. N., LaPlante, S. R., Kumar, A., Zanatta, N., Martin, A., Hakkinen, A., \& Levy, G. C. (1994) Biochemistry 33, 24412450.

Botuyan, M. V., Keire, D. A., Kroen, C., \& Gorenstein, D. G. (1993) Biochemistry 32, 6863-6874.

Chatterjee, P. K., \& Cantor, C. R. (1978) Nucleic Acids Res. 5 , 3619-3633.

Cheng, S., Sancar, A., \& Hearst, J. E. (1991) Nucleic Acids Res. $19,657-663$.

Cimino, G. D., Gamper, H., Isaacs, S., \& Hearst, J. E. (1985) Annu. Rev. Biochem. 54, 1151-1193.

Cimino, G. D., Gamper, H., Isaacs, S., \& Hearst, J. E. (1985) Annu. Rev. Biochem. 54, 1151-1193.

Cimino, G. D., Shi, Y., \& Hearst, J. E. (1986) Biochemistry 25, 3013-3020.

Crothers, D. M., Gartenberg, M. R., \& Shrader, T. E. (1991) Methods Enzymol. 208, 118-146.

Drew, H. R., \& Travers, A. A. (1985) J. Mol. Biol. 186, 773-790.

Dugas, H. (1977) Acc. Chem. Res. 10, 47.

Eimer, W., Williamson, J. R., Boxer, S. G., \& Pecora, R. (1990) Biochemistry 29, 799-811.

Emsley, L., Dwyer, T. J., Spielmann, H. P., \& Wemmer, D. E. (1993) J. Am. Chem. Soc. 115, 7765-7771.

Gamper, H., Piette, J., \& Hearst, J. E. (1984) Photochem. Photobiol. 40, 29-34.

Gao, Q., Williams, L. D., Egli, M., Rabinovich, D., Chen, S. L., Quigley, G. J., \& Rich, A. (1991) Proc. Natl. Acad. Sci. U.S.A. $88,2422-2426$.

Garcia, A., Lambert, I. B., \& Fuchs, R. P. (1993) Proc. Natl. Acad. Sci. U.S.A. 90, 5989-5993.

Huang, J. C., Hsu, D. S., Kazantsev, A., \& Sancar, A. (1994) Proc. Natl. Acad. Sci. U.S.A. 91, 12213-12217.

Hustedt, E. J., Spaltenstein, A., Kirchner, J. J., Hopkins, P. B., \& Robinson, B. H. (1993) Biochemistry 32, 1774-1787.

Hustedt, E. J., Kirchner, J. J., Spaltenstein, A., Hopkins, P. B., \& Robinson, B. H. (1995) Biochemistry 34, 4369-4375.

Isaacs, S. T., Shen, C.-K. J., Hearst, J. E., \& Rapoport, H. (1977) Biochemistry 16, 1058-1064

Isaacs, S., Rapoport, H., \& Hearst, J. E. (1982) J. Labelled Compd. Radiopharm. 19, 345.

Kamzolova, S. G., \& Postnikova, G. B. (1981) Q. Rev. Biophys. 14,223

Kanne, D., Straub, K., Hearst, J. E., \& Rapoport, H. (1982a) J. Am. Chem. Soc. 104, 6754-6764.

Kanne, D., Straub, K., Rapoport, H., \& Hearst, J. E. (1982b) Biochemistry 21, 861-871.

Kao, J. Y., Golijer, I., Phan, T. A., \& Bolton, P. H. (1993) J. Biol. Chem. 268, 17787-17793.

Kao, S. C., \& Bobst, A. M. (1985) Biochemistry 24, 5563-5568.

Karslake, C., Botuyan, M. V., \& Gorenstein, D. G. (1992) Biochemistry 31, 1849-1858.

Keana, J. F. W. (1978) Chem. Rev. 78, 37.

Keana, J. F. W., Keana, S. B., \& Lee, T. D. (1975) J. Am. Chem. Soc. $87,3055$.

Kirchner, J. J., Hustedt, E. J., Robinson, B., \& Hopkins, P. (1990) Tetrahedron Lett. 31, 593-596.

Koudelka, G. B., Harbury, P., Harrison, S. C., \& Ptashne, M. (1988) Proc. Natl. Acad. Sci. U.S.A. 85, 4633-4637.

Lambert, B., Segal-Bendirdjian, E., Esnault, C., LePecq, J. B., Roques, B. P., Jones, B., \& Yeung, A. T. (1990) Anti-Cancer Drug Des. 5, 43-53.

Lee, T. D., \& Keana, J. F. W. (1975) J. Org. Chem. 40, 31453147. 
Likhtenstein, G. I. (1976) in Spin Labeling Methods in Molecular Biology, Wiley, New York.

Lin, J. J., \& Sancar, A. (1989) Biochemistry 28, 7979-7984.

Maniatis, T., Fritsch, E. F., \& Sambrook, J. (1982) in Molecular Cloning, pp 125-126, Cold Spring Habor Laboratory, Cold Spring Harbor, NY.

Nuutero, S., Fujimoto, B. S., Flynn, P. F., Reid, B. R., Ribeiro, N. S., \& Schurr, J. M. (1994) Biopolymers 34, 463-480.

O'Handley, S. F., Sanford, D. G., Xu, R., Lester, C. C., Hingerty, B. E., Broyde, S., \& Krugh, T. R. (1993) Biochemistry 32, 24812497.

Opella, S. J., Wise, W. B., \& DiVerdi, J. A. (1981) Biochemistry 20, 284-290.

Pauly, G. T., Thomas, I. E., \& Bobst, A. M. (1987) Biochemistry 26, 7304-7310.

Plum, G. E., Grollman, A. P., Johnson, F., \& Breslauer, K. J. (1992) Biochemistry 31, 12096-12102.

Pu, W. T., Kahn, R., Munn, M. M., \& Rupp, W. D. (1989) J. Biol. Chem. 264.

Rauckman, E. J., \& Rosen, G. M. (1976a) Synth. Commun. 6, 325.

Rauckman, E. J., Rosen, G. M., \& Abou-Donia, M. B. (1976b) Org. Prepr. Proced. Int. 8, 159.

Reardon, J. T., Spielmann, P., Huang, J.-C., Sastry, S., Sancar, A., \& Hearst, J. E. (1991) Nucleic Acids Res. 19, 4623-4629.

Robinson, B. H., Lerman, L. S., Beth, A. H., Frisch, H. L., Dalton, L. R., \& Auer, L. (1980) J. Mol. Biol. 139, 19-44.

Sancar, A., \& Hearst, J. E. (1993) Science 259, 1415-1420.

Sancar, A., \& Sancar, G. B. (1988) Annu. Rev. Biochem. 57, 2967.

Satchwell, S. C., Drew, H. R., \& Travers, A. A. (1986) J. Mol. Biol. 191, 659-675.

Schneider \& Freed (1989) in Spin-Labeling Theory and Applications 8 , Plenum, New York.

Schulz, S. C., Shields, G. C., \& Steitz, T. A. (1991) Science 253, $1001-1007$

Schurr, J. M., Fujimoto, B. S., Wu, P., \& Song, L. (1992) in Topics in Fluorescence Spectroscopy, Volume 3, Biochemical Applications (Lakowicz, J. R., Ed.) pp 137-229, Plenum Press, New York.
Selby, C. P., \& Sancar, A. (1991) Biochemistry 30, 3841-3849. Shi, Q., Thresher, R., Sancar, A., \& Griffith, J. (1992) J. Mol. Biol. $226,425-432$.

Shi, Y., \& Hearst, J. E. (1986) Biochemistry 25, 5895-5902.

Shi, Y., Griffith, J., Gamper, H., \& Hearst, J. E. (1988) Nucleic Acids Res. 16, 8945-8952.

Shi, Y., Lipson, S., Chi, D. Y., Spielmann, H. P., Monforte, J., \& Hearst, J. E. (1990) Applications of Psoralens as Probes of Nucleic Acid Structure and Function in Bioorganic Photochemistry: Photochemistry and the Nucleic Acids, 1st ed., pp 341-378, John Wiley \& Sons, New York.

Sladek, F. M., Munn, M. M., Rupp, W. D., \& Howard-Flanders, P. (1989) J. Biol. Chem. 264, 6755-6765.

Smith, C. A. (1988) Repair of DNA Containing Furocoumarin Adducts. Psoralen DNA Photobiology, pp 87-116, CRC Press, Inc., Boca Raton, FL.

Smith, K. C., Wang, T.-C. V., \& Sharma, R. C. (1989) BioEssays $10,12-16$.

Spaltenstein, A., Robinson, B., \& Hopkins, P. B. (1989) Biochemistry 28, 9484-9495.

Spielmann, H. P., Sastry, S. S., \& Hearst, J. E. (1992) Proc. Natl. Acad. Sci. U.S.A. 89, 4514-4518.

Spielmann, H. P., Dwyer, T. J., Sastry, S. S., Hearst, J. E., \& Wemmer, D. E. (1995) Proc. Natl. Acad. Sci. U.S.A. 92, 23452349.

Straub, K., Kanne, D., Hearst, J. E., \& Rapoport, H. (1981) J. Am. Chem. Soc. 103, 2347-2355.

Tirado, M. M., \& Garcia de la Torre, J. (1979) J. Chem. Phys. 71, $2581-2587$.

Tirado, M. M., \& Garcia de la Torre, J. (1980) J. Chem. Phys. 73, 1986-1993.

Van Houten, B., Gamper, H., Hearst, J. E., \& Sancar, A. (1987) J. Biol. Chem. 262, 13180-13187.

Van Houten, B., Gamper, H., Sancar, A., \& Hearst, J. E. (1988) J. Biol. Chem. 263, 16553-16560.

Williams, L. D., \& Gao, Q. (1992) Biochemistry 31, 4315-4234.

B1950207I 